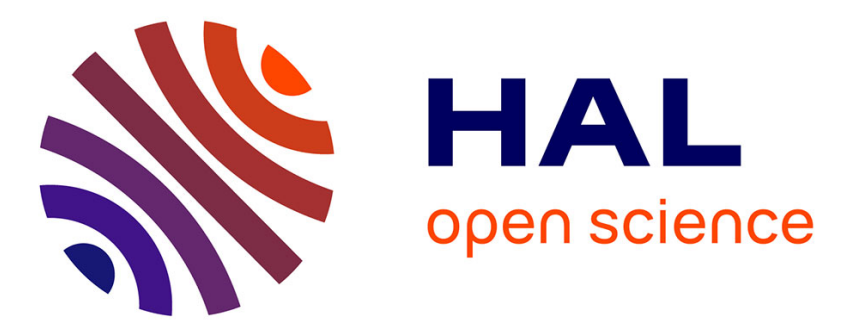

\title{
Mineral resource assessment: Compliance between Emergy and Exergy respecting Odum's hierarchy concept
}

\author{
Nadia Jamali-Zghal, Olivier Le Corre, Bruno Lacarrière
}

\section{To cite this version:}

Nadia Jamali-Zghal, Olivier Le Corre, Bruno Lacarrière. Mineral resource assessment: Compliance between Emergy and Exergy respecting Odum's hierarchy concept. Ecological Modelling, 2014, 272, pp.208-219. 10.1016/j.ecolmodel.2013.09.017 . hal-00879451

\section{HAL Id: hal-00879451 \\ https://hal.science/hal-00879451}

Submitted on 4 Nov 2013

HAL is a multi-disciplinary open access archive for the deposit and dissemination of scientific research documents, whether they are published or not. The documents may come from teaching and research institutions in France or abroad, or from public or private research centers.
L'archive ouverte pluridisciplinaire HAL, est destinée au dépôt et à la diffusion de documents scientifiques de niveau recherche, publiés ou non, émanant des établissements d'enseignement et de recherche français ou étrangers, des laboratoires publics ou privés. 


\title{
Mineral resource assessment: Compliance between Emergy and Exergy respecting Odum's hierarchy concept
}

\author{
N. Jamali-Zghal ${ }^{\mathrm{a}}$, O. Le Corre ${ }^{\mathrm{a}, *}$, B. Lacarrière ${ }^{\mathrm{a}}$ \\ ${ }^{a}$ Dpt. Système Energètiques et Environnement, Ecole des Mines de Nantes, La Chantrerie, 4 rue A. \\ Kastler, BP 20722, Nantes Cedex 3, France
}

\begin{abstract}
In this paper, authors suggest to combine the exergoecology and the emergy concept in order to evaluate mineral resources, taking into account their abundance, their chemical and physical properties and the impact of their extraction. The first proposition of this work is to consider that every group of mineral, dispersed in the Earth's crust, is a co-product of the latter. The specific emergies of dispersed minerals are, then, inversely proportional to their abundance. The results comply with the material hierarchy as the specific emergy of a dispersed mineral rise with its scarcity. The second is an emergy evaluation model based on the chemical and concentration exergy of the mineral, its condition in the mine and its abundance. This model permits to assess the decline of mineral reserves and its impact on the ecosystem. The dispersed specific emergy of 42 main commercially used minerals has been calculated. Furthermore, the emergy decrease of some Australian mineral reserves has been studied, as well as the land degradation of US copper mines.

Keywords: Emergy, Exergoecology, Mineral resource depletion, Material hierarchy
\end{abstract}

\section{Introduction}

Emergy can be considered as an "energy footprint" which memorizes all energies in their original forms, converted in solar energy (seJ, Solar emjoule), consumed or transformed to create a product or a service (Odum, 1996). As the production complexity and the ability to do work can be very different from one form of energy to another, the emergy concept posits that the energy flows of the universe are organized in an energy

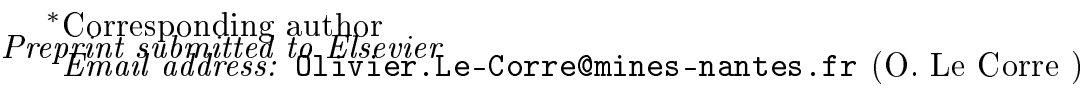

September 23, 2013 
transformation hierarchy (Odum, 1996; Brown and Ulgiati, 2004). The position of any kind of energy in this hierarchy is given by its transformity which is by definition, the ratio between the emergy contribution (input) and the exergy (output). While assuming that the real wealth of the environment is the work of the geobiosphere, the annual emergy flow of the geobiosphere is considered to be the baseline reference from which all other unit emergy flows are directly or indirectly derived from (Odum, 2000b; Brown and Ulgiati, 2010).

To evaluate mineral resources Odum proposed what he called 'the $6^{\text {th }}$ energy law' (see Citation 1) to relate material cycles to the energy hierarchy concept, which permits to classify hierarchically materials from the point of their specific emergies (seJ/g). The emergy concept posits that the universe is hierarchically classified, describing the diminution of available energy with each transformation process. The transformity, defined as the emergy driving the process per unit of available energy, indicates the position of any transformation process in the hierarchy, since the latter enhances the quality of the produced energy but reduces the amount of available energy. Thus, the greater the transformity is, the more available energy of a lower level of the hierarchy has been involved in the transformation process. The same reasoning can be applied to material cycles: the concentration of dispersed minerals requires available energy i.e. the higher the concentration of the mineral deposit is the more available energy has been downgraded and the higher the emergy per mass should be. Otherwise, when concentrated minerals becomes dispersed, available energy is lost and the stored emergy diminishes.

\section{Citation 1 (An energy hierarchy law for biochemical cycles)}

«Materials of biochemical cycles are hierarchically organized because of the necessary coupling of matter to the universal energy transformation hierarchy» (Odum (2000a))

Previous studies (Cohen et al., 2007; Brown, 2007) have been carried out to evaluate the emergy of mineral resources, expecting that the specific emergy of a mineral reserve 
$e m_{R}$ varies linearly with its enrichment factor $E F_{R}$, see Equation 1.

$$
e m_{R}=B_{R} \cdot E F_{R}
$$

Cohen et al. (2007) and Brown (2007) used both an enrichment factor based on the ore grade cutoff $O G C$ and the crustal concentration $x_{M_{c r}}$ of the mineral, which is by definition the minimum ore grade a mine should have to be exploited profitably. The value is very variable, it depends essentially on the current level of technology and the market demand of the mineral. An universal baseline $B_{R}$ was applied because the different rock types from which the minerals are extracted, are considered to have little varying specific emergies. Cohen et al. (2007) first, used the specific emergy of land cycle (calculated by Odum (1996)) as baseline. Brown (2007), later, updated this work by adopting the specific emergy of the Earth's crust that he calculated. In addition, a regression model relating the cutoff concentration to the price and abundance has been elaborated to estimate the specific emergy of those minerals for which the cutoff concentration were not available. The results of these studies, however, as they are based on the ore grade cutoff of the mineral, do not represent the real emergy that Nature invested to create the mineral reserve, but rather an evaluation in view of standards set by society, because the results only reveals the minimum specific emergy a reserve should have to be beneficially extracted. Besides, integrating market prices to estimate the specific emergy of ore deposits seems not to be an adequate solution because the prices rarely vary with the condition of the mineral in the mine but often with economic, financial and geopolitical circumstances. Thus, the highest specific emergy obtained by this approach do not correspond to scarce materials as expected by Odum who emphasized in his book that scarce minerals require more work for their creation and concentration (see Citations 2 and Citations 3), but to those with high ore grade cutoffs. This shows that the evaluation of mineral resources by this method is limited in particular because the chemical composition and the decline of the reserves 
80

81

84

87

is not taken into account.

\section{Citation 2 (Environmental accounting)}

«Emergy per unit mass (seJ/g) indicates the position a mineral has on the scale of Earth scarcity and unit value.» (Odum (1996), p.121)

\section{Citation 3 (Environmental accounting)}

«In general, the scarce products from the Earth are those that required more work for their formation and concentration. Therefore they tend to have higher Emergy contents. Burnett (1981) found that materials with more emergy contribution were less abundant.» (Odum (1996), p.117)

Several scientists even goes further in their criticism, claiming that contrarily to exergy analysis, emergy evaluation is not suitable to assess mineral resources. Martinez et al. (2007) concluded, after comparing the evaluation of Earth's mineral resources via both emergy and exergy analysis that the latter method is more adequate for accurate mineral valuation. Sciubba (2010) stated that emergy accounting is unable to evaluate the degradation of mineral resources caused by human consumption, see Citation 4 . As well as Valero et al. (2008) who contested the rigorousness of mineral resource assessment via emergy analysis, see Citation 5 .

Actually, when exergy analyses are used to evaluate natural capital, it should be kept in mind that exergy is a state function. Thus, it does not describe the processes that generated natural capital, but only the results of theses processes i.e. the distance from their thermodynamic equilibrium, without any consideration for the followed path and for the origin of the required energy. It can therefore be concluded that the exergy method permits to assess accurately the energy required to replace mineral resources with present technology but that it is unable to evaluate the work that was done by Nature to form ore deposits. 
The aim of this paper is to combine the emergy and the exergy approach, in order to evaluate the real wealth of mineral resources, taking into account their physical and chemical conditions and the driving forces behind their evolution. This work try to develop a methodology that permits not only to quantify the quality decrease of ore deposits during mining but also to illustrate the impact caused by mineral extraction and the work that should be done to restore the post-mining land.

\section{Citation 4 (On the Second-Law inconsistency of Emergy Analysis)}

«It is recommended therefore that Emergy Analysis be not used to assess the global resource consumption caused by anthropic activities, because its results are misleading when it comes to estimate the exergy destruction enacted by real industrial transformations.» (Sciubba (2010))

\section{Citation 5 (Exergy evolution of the mineral capital on earth)}

«No matter how much solar energy is received from the sun, the quantity of gold or iron for instance on Earth, will not change. Consequently, the rigorousness of the transformities for mineral resource assessment is doubtful.» (Valero et al. (2008), p.8)

\section{Methodology}

\subsection{Scope of the study}

The production of non-fuel minerals for economic use involves a series of physical and chemical processes, see Figure 1. These complex processes are either natural or manmade, therefore it is recommended to distinguish between natural and anthropogenic exergy in assessing mineral resources. The minerals' natural exergy represents the effort invested by Nature to create them with their chemical and physical properties as they are found in the mine. The minerals' anthropogenic exergy, however, represents the energies that should be mobilized by man to make the mineral suitable for commercial 
use.

In this work only the natural exergy of the mineral has been studied with the aim of quantifying the environmental impact of mineral resource depletion.

\subsection{Exergy analysis of non-fuel mineral reserves}

Minerals are limited, non-renewable natural resources offered by Nature and exploited by human society. Any natural resource is characterized by its specific composition and concentration, which distinguish it from its environment. These intrinsic properties permit to measure the thermodynamic value of a natural resource, called material's exergy (Riekert, 1974), which is defined as the minimum theoretical work that Nature should invest to produce it with its specific structure and concentration. A number of exergy-based approaches have been proposed to evaluate natural resources. The most common concept may be the Thermo-ecological cost analysis introduced by Szargut et al. (2002). This method proposes to measure, in terms of exergy and energy, the ecological cost of non-renewable natural resource depletion. Therefore the cumulative consumption of non-renewable exergy connected with the fabrication of particular products, including the abatement processes of the resulting emissions and wastes is accounted for. The exergoecology approach, introduced by Valero (1998) and used in this study, differs fundamentally from Szargut's method as it is not interested in the exergy costs of the production processes but rather on the physical cost that would be required to produce, with today's best technology, natural resources from its components in a defined reference environment (which is assigned as the most degraded state of the resource) to the physical and chemical conditions as they are found in Nature. This thermodynamic tool permits to provide a realistic value of the energy that Nature stored in form of concentrated mineral resources and that will be irreversibly lost when these minerals are used up. It should be noted that the exergoecology should not be confused with with the eco-exergy concept, introduced by Jorgensen (2006) and applied to measure the development and health of an ecosystem 


\subsubsection{Exergy of non-fuel minerals}

In this work, the thermodynamic evaluation of minerals is based on Szargut's reference environment methodology (Szargut et al., 2005). The chemical composition and the thermodynamic properties of this hypothetical environment permits to calculate the theoretical minimum work that must be invested to reproduce from the reference substances the composition of the Earth crust, in form of a homogeneous solid layer where all minerals are uniformly distributed at their average concentration $x_{M_{c r}}$. The reference environment is considered as a source of heat and reference substances. The process is assumed to be reversible. The mineral's specific chemical exergy ex $x_{c h M}$ can be calculated by using the exergy balance of a reversible reaction, as the reference substances are supposed to be at a standard ambient temperature and pressure and standard concentration in the natural environment (Szargut, 1989; Valero et al., 2002a), see Equation 2.

$$
e x_{c h M}=\Delta g_{f}+\sum_{i} y_{i} \cdot e x_{c h i}
$$

$\Delta g_{f}$ represents the specific Gibbs free energy of mineral $M$ and $y_{i}$ and $e x_{c h i}$ are respectively the molar fraction and the specific chemical exergy of component $i$ of mineral $M$.

Ore deposits are naturally occurring aggregates of minerals, their ore grade represents the mineral content of the rock which is much higher than the average concentration of the mineral in the Earth's crust. Concentrated minerals in mines can be easily extracted with present technology, compared to other parts of the Earth's crust where the mineral is dispersed. Thus, according to Szargut's reference environment methodology, any mineral resource with higher concentration would have an amount of energy provided by Nature, which differentiate it from its dispersed state in the reference environment. The concentration exergy is defined by Valero et al. (2009) to be the minimum required work to concentrate, in a reversible way, the dispersed mineral 
in the Earth's crust into mines. Assuming, that an ore deposit is an ideal mixture of a mineral $M$ and rock, the specific concentration exergy of the mineral $e x_{c M}$ can be equated to the minimum amount of work that should be furnished to separate the mineral (concentrated at $x_{M}$ ) from the rock, see Equation 3. It can be seen that the higher the ore grade, the lower the effort needed to extract the mineral from the mine, pointing to the fact that concentrated minerals represent a natural energy contribution, easing its extraction.

$$
e x_{c M}\left(x_{M}\right)=-R T^{\circ}\left\{\ln \left(\lambda_{M} x_{M}\right)+\frac{\left(1-\lambda_{M} x_{M}\right)}{\lambda_{M} x_{M}} \ln \left(1-\lambda_{M} x_{M}\right)\right\}
$$

Where $R$ represents the universal gas constant, $T^{\circ}$ the standard ambient temperature and $\lambda_{M}$ the molar mass ratio between the mineral and the mixture of rock and mineral.

Valero identifies three theoretical states of mineral evolution to calculate the exergy that should be invested to form mineral deposits from the reference environment, see Figure 2:

1. State 0 (Reference environment): All the reference substances are dispersed, mixed and in thermodynamic equilibrium $\Rightarrow$ The exergy is Zero.

2. State 1 (Dispersed minerals): Chemical reactions took place, the minerals are formed and dispersed at their crustal concentration $x_{M_{c r}}$ on the Earth crust, the specific exergy of the dispersed mineral $e x_{M}\left(x_{M_{c r}}\right)$ of the mineral is:

$$
e x_{M}\left(x_{M_{c r}}\right)=e x_{c h M}
$$

3. State 2 (Concentrated minerals): The dispersed mineral is concentrated at $x_{M}$ into mines, the specific exergy of the concentrated mineral $e x_{M}\left(x_{M}\right)$ is then: 


$$
e x_{M}\left(x_{M}\right)=e x_{c h M}+e x_{c M}\left(x_{M}\right)
$$

Valero's evaluation model (Valero et al., 2002b) is based on hypothetical reversible conditions, far from real processes where friction and dissipation losses can not be neglected. The real exergy requirements are, then, much more greater than the thermodynamic value which represents only the minimum work that should be invested to form a given mineral from the reference environment to the conditions in the mine. In this context, Valero proposes to introduce physical unit costs, $k_{c h M}$ and $k_{c M}$, respectively of the refining and the concentration process of the mineral. This permits to identify the real exergetic value of minerals, taking into account the limits of the current available technology, see Equation 6.

$$
e x_{M}^{r}\left(x_{M}\right)=k_{c h M} \cdot e x_{c h M}+k_{c M} \cdot e x_{c M}\left(x_{M}\right)
$$

\subsubsection{Exergy decrease of declining non-fuel mineral reserves}

The exergy of a mineral reserve depends on the grade and size of the ore body. To evaluate the exergy lost by mineral extraction, the whole life cycle of the reserve should be considered, from its formation until its depletion. Three main theoretical stages can be distinguished:

- Calculation of the ore deposit's chemical exergy (pre-mine), The mineral is dispersed at its crustal concentration $x_{M_{c r}}$. The specific exergy of the mineral reserve $e x_{R}\left(x_{M_{c r}}\right)$ is, then, equal to the real specific exergy of the dispersed mineral $e x_{M}^{r}\left(x_{M_{c r}}\right)$. Its absolute exergy $E x_{R}\left(x_{M_{c r}}\right)$ tends to zero as the mass of extractable mineral $m_{M}$ is still negligible:

$$
\begin{aligned}
& e x_{R}\left(x_{M_{c r}}\right)=e x_{M}^{r}\left(x_{M_{c r}}\right)=k_{c h M} \cdot e x_{c h M} \\
& E x_{R}\left(x_{M_{c r}}\right) \rightarrow 0
\end{aligned}
$$


It should be noted that only concentrated chemical exergy can be used because it is impossible to extract dispersed minerals with present technology.

- Calculation of the ore deposit's concentration exergy (enrichment), The mine is viewed as the result of a natural enrichment process with concentrated minerals. Before extraction, the initial specific exergy of the mineral reserve $e x_{R}\left(x_{M}^{\circ}\right)$, is then equal to the real specific exergy of the concentrated mineral $e x_{M}\left(x_{M}^{\circ}\right)$. At this stage the stored exergy $E x_{R}\left(x_{M}^{\circ}\right)$ reaches its maximum.

$$
\begin{aligned}
e x_{R}\left(x_{M}^{\circ}\right) & =e x_{M}^{r}\left(x_{M}^{\circ}\right)=k_{c h M} \cdot e x_{c h M}+k_{c M} \cdot e x_{c M}\left(x_{M}^{\circ}\right) \\
E x_{R} & =m_{M}^{\circ} \cdot M_{M} \cdot e x_{R}\left(x_{M}^{\circ}\right)
\end{aligned}
$$

$m_{M}^{\circ}$ is the initial total mass of mineral in the mine, $M_{M}$ is the molar mass of the mineral and $x_{M}^{\circ}$ is the initial ore grade of the mine.

- Calculation of the ore deposit's exergy decrease (depletion), During extraction, the ore grade $x_{M}$ of the reserve is diminishing $\left(x_{M_{c r}} \leq x_{M} \leq x_{M}^{\circ}\right)$ and the mineral reserve is losing exergy.

$$
\begin{aligned}
& e x_{R}\left(x_{M}\right)=e x_{M}^{r}\left(x_{M}\right)=k_{c h M} \cdot e x_{c h M}+k_{c M} \cdot e x_{c M}\left(x_{M}\right) \\
& E x_{R}\left(x_{M}\right)=m_{M} \cdot M_{M} \cdot e x_{R}\left(x_{M}\right)
\end{aligned}
$$

$m_{M}$ is the remaining mass of mineral in the deposit after extraction and $x_{M}$ is its corresponding ore grade. It should be stressed that the concentration exergy of the mineral decreases with its ore grade, while the chemical exergy remains constant. When all the mineral is extracted, the mine becomes depleted, the extractable quantity of mineral $m_{M}$ becomes insignificant, and hence its ore grade $x_{M}$ tends to the crustal concentration of the mineral $x_{M_{c r}}$. The specific exergy of the reserve $e x_{R}$ tends then to its specific exergy before enrichment and the stored absolute exergy $E x_{R}$ becomes negligible: 


$$
\begin{aligned}
\lim _{x_{M} \rightarrow x_{M_{c r}}} e x_{R}\left(x_{M}\right) & =k_{c h M} \cdot e x_{c h M} \\
\lim _{x_{M} \rightarrow x_{M_{c r}}} E x_{R}\left(x_{M}\right) & =0
\end{aligned}
$$

Figure 3 represents the specific exergy of the mineral reserve at different evolution stages. It can be seen that the exergy analysis distinguishes two main energy levels, a degraded one and an enriched one, corresponding respectively to the dispersed and the concentrated state of the mineral.

\subsection{Emergy evaluation model of non-fuel mineral reserves}

An emergy evaluation model is proposed that permits to assess the impact of declining non fuel mineral reserves. This method permits to assess on the one hand the emergy that Nature invested to form mineral deposits and on the other hand the emergy required to compensate the damages caused by mining.

\subsubsection{Emergy decrease of declining non-fuel mineral reserves}

In order to evaluate the emergy that would be lost by extracting the mineral from the mine, the emergy required to create such mineral reserves should be determined. Three main theoretical evolution processes ought to be taken into account, see Figure 4 .

1. Earth's crust formation process: Hazen's mineral evolution theory (Hazen, 2010; Hazen and Ferry, 2010) and other proposed scenarios of Earth's crust formation (McCoy, 2010; Valley et al., 2002; Jørgensen et al., 2009; Sverjensky, 2010) illustrate the complexity and breath of the processes that participated, over eons, in developing the mineralogy of the Earth's crust to its present diversification and distribution. It will be very difficult if not impossible to determine exactly the energies that drove terrestrial mineral evolution, because little is known about these processes which are no longer observed in today's world. Nevertheless, different studies had been performed to evaluate the emergy of the Earth's crust. Based on the work of Garrels et al. (1975), Odum (1996) estimated the specific 
emergy of global sediment to be about $1.62 \mathrm{E}+9 \mathrm{seJ} / \mathrm{g}$. Brown (2007) calculated a specific emergy of the Earth's crust of about $1.35 \mathrm{E}+8 \mathrm{seJ} / \mathrm{g}$, assuming a turnover time of $2.5 \mathrm{E}+8$ yrs (the values have been converted into the emergy baseline of $1.52 \mathrm{E}+24 \mathrm{seJ} / \mathrm{yr}$ (Brown and Ulgiati, 2010)). In the next section, a methodology is proposed to calculate the emergy of Earth's crust formation by using its chemical exergy.

Every group of mineral dispersed in the Earth's crust is regarded as individual component of the latter, characterized by its specific chemical composition and its abundance, and thus it may be considered, from an emergy point of view, as co-product of the Earth's crust formation process, see Figure 4. This means that every group of mineral has the same absolute emergy as the Earth's crust and that its specific emergy $e m_{M}\left(x_{M_{c r}}\right)$ is proportional to the specific emergy of the Earth's crust $e m_{c r}$ and to its crustal concentration $x_{M_{c r}}$, see Equation 11:

\section{Assumption 1 (Emergy of dispersed minerals)}

Every group of mineral is assumed to be a co-product of the Earth's crust: The absolute emergy of any mineral group $\operatorname{Em}_{M}\left(x_{M_{c r}}\right)$ is equal to the absolute emergy of the Earth's crust Em $m_{c r}$.

$$
E m_{M}\left(x_{M_{c r}}\right) \stackrel{\text { def }}{=} E m_{c r}
$$

$m_{M_{c r}}$ represents the mass of the mineral in the Earth's crust and $m_{c r}$ represents the total mass of the Earth's crust. Hence the specific emergy of a dispersed mineral $M, e m_{M}\left(x_{M_{c r}}\right)$ can be expressed as follows:

$$
\begin{aligned}
m_{M_{c r}} & =x_{M_{c r}} \cdot m_{c r} \\
e m_{M}\left(x_{M_{c r}}\right) & =\frac{E m_{c r}}{m_{M_{c r}}} \\
& =\frac{e m_{c r}}{x_{M_{c r}}}
\end{aligned}
$$

Odum (see Citation 2) emphasized that the emergy per mass (or specific emergy) of a mineral vary with its abundance in the Earth's crust. The more the mineral 
is abundant the lower the emergy contribution was to create it. The results of Equation 11 meets exactly what Odum expected (Citation 2 and Citation 3), scarce minerals present higher emergy contribution than abundant one. It should be noted, that $\mathrm{em}_{M}\left(x_{M_{c r}}\right)$ represents the lowest position of the mineral in the material hierarchy, because the mineral cannot be dissipated spontaneously further than its crustal concentration $x_{M_{c r}}$.

\section{Citation 6 (An energy hierarchy law for biochemical cycles )}

$« \ldots$ any increase in concentration of material requires an increase in the energy per mass. When concentration increase in some part of a biogeochemical cycle, the emergy per mass increases.» ( Odum (2000a))

2. Concentration of minerals into ore deposits: Odum (Citation 6) stressed that compared to its dispersed state (at crustal concentration $x_{M_{c r}}$ ), concentrated minerals required more work to be formed and thus, the more the mineral is concentrated the more available energy had been degraded and the higher the emergy per mass will be (i.e. the higher its position in the material hierarchy). Actually, the quality of a mineral reserve depends on the quantity $m_{M}^{\circ}$ and on the concentration of the stored mineral $x_{M}^{\circ}$. In this work, it is considered that the same sources of energy ( $\tau_{F}$ is the average transformity of these sources) that created dispersed minerals, concentrated further a part of them into mines, see Figure 4. Thus, the specific emergy of the mineral reserve $e m_{R}$ can be calculated by using the mineral's exergy, the specific emergy of the dispersed mineral $e m_{M}\left(x_{M_{c r}}\right)$ and the ore grade of the deposit $x_{M}^{\circ}$.

Assumption 2 (Emergy of mineral reserves)

The sources of energy that created dispersed minerals in the Earth's crust are 
expected to be the same source that concentrated a part of them into mineral reserves.

$$
\tau_{F} \stackrel{\text { def }}{=} \frac{E m_{M}\left(x_{M_{c r}}\right)}{E x_{M}\left(x_{M_{c r}}\right)} \stackrel{\text { def }}{=} \frac{E m_{R}\left(x_{M}^{\circ}\right)}{E x_{R}\left(x_{M}^{\circ}\right)}
$$

The initial specific emergy $e m_{R}\left(x_{M}^{\circ}\right)$ of an ore reserve of mineral $M$ with an ore grade $x_{M}^{\circ}$ can be calculated, then, by using Equation 13 :

$$
\begin{aligned}
e m_{R}\left(x_{M}^{\circ}\right) & =e m_{M}\left(x_{M_{c r}}\right) \cdot \frac{e x_{R}\left(x_{M}^{\circ}\right)}{e x_{M}\left(x_{M_{c r}}\right)} \\
& =\frac{e m_{c r}}{x_{M_{c r}}} \cdot\left[\frac{k_{c h M} \cdot e x_{c h M}+k_{c M} \cdot e x_{c M}\left(x_{M}^{\circ}\right)}{k_{c h M} \cdot e x_{c h M}}\right] \\
& =\frac{e m_{c r}}{x_{M_{c r}}} \cdot\left[1+\frac{k_{c M} \cdot e x_{c M}\left(x_{M}^{\circ}\right)}{k_{c h M} \cdot e x_{c h M}}\right]
\end{aligned}
$$

The total amount of emergy $E m_{R}\left(x_{M}^{\circ}\right)$ stored initially in the mine can be expressed as follows:

$$
E m_{R}\left(x_{M}^{\circ}\right)=m_{M}^{\circ} \cdot e m_{R}\left(x_{M}^{\circ}\right)
$$

It should be underlined that $\operatorname{em}_{R}\left(x_{M}^{\circ}\right)$ and $E m_{R}\left(x_{M}^{\circ}\right)$ are the highest values the mine can ever reach during its life cycle.

It can be noted that the results of Equation 13 are consistent with the material hierarchy. The specific emergy of the mineral reserve increases with its ore grade $x_{M}^{\circ}$ and conversely when its ore content decline to its lowest value $\left(x_{M_{c r}}\right)$, the specific emergy of the deposit tends to its lowest level in the material's hierarchy, which corresponds to the crustal specific emergy of the mineral: 


$$
\lim _{x_{M}^{\circ} \rightarrow x_{M_{c r}}} e m_{R}=e m_{M}\left(x_{M_{c r}}\right)
$$

Besides, when the abundance of the mineral $x_{M_{c r}}$ tends to 1 (which means that the whole Earth's crust is composed of mineral M), the specific emergy of the mineral reserve tends to the specific emergy of the Earth's crust:

$$
\lim _{x_{M_{c r} \rightarrow 1}} e m_{R}=e m_{c r}
$$

In order that Equation 1 proposed by (Cohen et al., 2007) and (Brown, 2007) will be coherent with the material hierarchy concept, the enrichment factor is expected to express the real work that Nature had invested to concentrate the mineral and the baseline should be the minimum specific emergy the mineral could reach naturally when it is dispersed. Therefore, to enhance this methodology the results of Equation 13 may be used. Instead of an universal baseline $B_{R}$ for any mineral reserve, the crustal specific emergy of the corresponding mineral $e m_{M}\left(x_{M_{c r}}\right)$ is proposed, since its most natural degraded state is when it is dispersed. The enrichment factor $E R_{R}$ can be defined as the ratio between the specific exergy of the concentrated ore reserve $e x_{R}\left(x_{M}^{\circ}\right)$ and the crustal specific exergy of the mineral $e x_{M}\left(x_{M_{c r}}\right)$. This permits to integrate the effort invested by Nature to upgrade the mineral from its dispersed state to its concentrated state in the mine.

\section{Proposition 1 (Baseline and enrichment factor of mineral reserves)}

The baseline is assumed to be the crustal specific emergy of the mineral: 


$$
B_{R}\left(x_{M_{c r}}\right) \stackrel{\text { def }}{=} e m_{M}\left(x_{M_{c r}}\right)
$$

The enrichment factor is defined as the ratio between the specific exergy of the concentrated ore reserve $e x_{R}\left(x_{M}^{\circ}\right)$ and the crustal specific exergy of the mineral ex $x_{M}\left(x_{M_{c r}}\right)$ :

$$
E F_{R}\left(x_{M}^{\circ}\right) \stackrel{\text { def }}{=} \frac{e x_{R}\left(x_{M}^{\circ}\right)}{e x_{M}\left(x_{M_{c r}}\right)}
$$

It should be underlined that for an appropriate emergy evaluation, first the sources and pathways should be identified. Thus, it seems unreal to equate, as done in Equation 1, the specific emergy of mineral reserves without considering their formation process. Therefore, Proposition 1 was made after defining a theoretical evolution process of mineral reserves, illustrated in Figure 4. The results reflects, then, the pathway of mineral reserve formation as the specific emergy of the reserve depends on the chemical properties and abundance of the mineral and the initial conditions of the reserve, see Equation 13.

\section{Citation 7 (An energy hierarchy law for biochemical cycles)}

«When material disperses, the stored emergy decreases.» (Odum $(2000 a))$

3. Extraction of the mineral from the mine: Owing to its chemical and concentration potential, a mineral reserve can be considered as an emergy reservoir furnished by Nature to meet human needs. With the extracted mineral the mine loses chemical and concentration potential, the mineral content $m_{M}$ and grade $x_{M}$ of the ore body diminishes $\left(m_{M}<m_{M}^{\circ} ; x_{M}<x_{M}^{\circ}\right)$ which leads to a reduction of its stored emergy. It is expected that, during the mining, not only the total 
emergy of the ore body $E m_{R}$ diminishes but also its specific emergy $e m_{R}$, as its concentration potential decreases with its ore grade. Complying with the energy hierarchy concept, see Citation 7 this means that during extraction, the mine loses its available energy (in form of chemical and concentration exergy) and descend, then, to a lower level in the energy hierarchy.

The present study is not concerned with assessing the work required to extract the mineral from the mine but instead with estimating the emergy that would be definitely lost due to mineral exploitation. Therefore, in order to calculate the variation of the specific emergy of the ore deposit with mining, the extraction of the mineral can be simulated by a natural dilution of the ore body generated by the same sources of energy that concentrated it before, see Figure 4. This means that the ore body of the reserve will be diluted from its initial ore grade $x_{M}^{\circ}$ to a lower concentration $x_{M}$ after mining.

\section{Assumption 3 (Emergy decrease of declining mineral reserves)}

The extraction of the mineral from the mine can be assimilated to a natural dilution of the ore body from its initial ore grade $x_{M}^{\circ}$ to a lower concentration $x_{M}$, generated by the same sources of energy that previously concentrated the mineral into the mine.

$$
\tau_{F} \stackrel{\text { def }}{=} \frac{E m_{R}\left(x_{M}^{\circ}\right)}{E x_{R}\left(x_{M}^{\circ}\right)} \stackrel{\text { def }}{=} \frac{E m_{R}\left(x_{M}\right)}{E x_{R}\left(x_{M}\right)}
$$

Thus the specific emergy of the declining ore reserve $e m_{R}\left(x_{M}\right)$ can be expressed as follows : 


$$
e m_{R}\left(x_{M}\right)=e m_{R}\left(x_{M}^{\circ}\right) \cdot \frac{e x_{R}\left(x_{M}\right)}{e x_{R}\left(x_{M}^{\circ}\right)}
$$

According to Equation 13:

$$
\begin{aligned}
e m_{R}\left(x_{M}\right) & =\frac{e m_{c r}}{x_{M_{c r}}} \cdot\left[\frac{k_{c h M} \cdot e x_{c h M}+k_{c M} \cdot e x_{c M}\left(x_{M}\right)}{k_{c h M} \cdot e x_{c h M}}\right] \\
& =\frac{e m_{c r}}{x_{M_{c r}}} \cdot\left[1+\frac{k_{c M} \cdot e x_{c M}\left(x_{M}\right)}{k_{c h M} \cdot e x_{c h M}}\right]
\end{aligned}
$$

The remaining stored emergy after mining $E m_{R}\left(x_{M}\right)$ with an ore grade $x_{M}$ containing a quantity $m_{M}$ of extractable mineral, is then:

$$
E m_{R}\left(x_{M}\right)=m_{M} \cdot e m_{R}\left(x_{M}\right)
$$

Once the ore reserve has been exhausted, its ore grade and specific emergy approaches respectively the crustal concentration $x_{M_{c r}}$ and the crustal specific emergy of the mineral $e m_{R}\left(x_{M_{c r}}\right)$. Theoretically, the consumed reserve is at the lowest position in the material hierarchy that it can ever attain naturally. The stored emergy of the reserve tends to zero. The chemical potential of the mineral in the mine is no longer exploitable.

$$
\begin{aligned}
\lim _{x_{M} \rightarrow x_{M_{c r}}} e m_{R}\left(x_{M}\right) & =e m_{M}\left(x_{M_{c r}}\right) \\
\lim _{x_{M} \rightarrow x_{M_{c r}}} E m_{R}\left(x_{M}\right) & =0
\end{aligned}
$$

Analogous to Equation 1, the specific emergy of a declining mineral reserve $e m_{R}\left(x_{M}\right)$ may be expressed, as a function of its baseline $B_{R}$ and its depletion factor $D F_{R}$. To be in conformity with the material hierarchy, the baseline should represent the highest specific emergy of the mine during its life cycle, and the depletion factor is expected to quantify the concentration ability of the mine at any stage of degradation. According to Equation 18, $\mathrm{em} \mathrm{m}_{R}\left(x_{M}^{\circ}\right)$ can be defined as 

the baseline of the reserve, the ratio between the specific exergy of the ore body after mining $e x_{R}\left(x_{M}\right)$ and the initial specific exergy of the mine $e x_{R}\left(x_{M}^{\circ}\right)$ can be considered as the depletion factor of the reserve.

\section{Proposition 2 (Baseline and depletion factor of declining mineral reserves)}

The initial specific emergy of the mineral is proposed as baseline:

$$
B_{R}\left(\stackrel{\circ}{x_{M}}\right) \stackrel{\text { def }}{=} e m_{R}\left(x_{M}^{\circ}\right)
$$

The depletion factor is defined as the ratio between the specific exergy of the ore body after mining $e x_{R}\left(x_{M}\right)$ and the initial specific exergy of the mine $e x_{R}\left(x_{M}^{\circ}\right)$ :

$$
D F_{R}\left(x_{M}\right) \stackrel{\text { def }}{=} \frac{e x_{R}\left(x_{M}\right)}{e x_{R}\left(x_{M}^{\circ}\right)}
$$

\subsubsection{Emergy evaluation of land degradation due to mining}

A mine can be considered as a part of the Earth's crust containing high concentrated mineral ores. The extraction of these ores not only causes the loss of mine's chemical and concentration potential but also the devastation of the landscape. Contrarily to the previous section where only the depletion of the mineral reserve has been studied, the present section deals with the degradation of the whole mine due to its exploitation and the efforts that should be applied to remedy the mining impacts.

The concentrated mineral content of the mine differentiates it from its environment. It can be assumed, then, that the total emergy of the mine $E m_{\text {Mine }}$ is equal to the total emergy of its mineral reserve $E m_{R}$.

\section{Assumption 4 (Emergy of mines)}

The total emergy of the whole mine Em Mine is equal to the total emergy of 
its mineral reserve $E m_{R}$ :

$$
\begin{aligned}
\operatorname{Em}_{\text {Mine }}\left(x_{M}\right) & =E m_{R}\left(x_{M}\right) \\
m_{M} & =x_{M} \cdot m_{\text {Mine }}
\end{aligned}
$$

$$
\begin{aligned}
e m_{\text {Mine }} & =x_{M} \cdot e m_{R}\left(x_{M}\right) \\
e m_{\text {Mine }}\left(x_{M}\right) & =e m_{c r} \cdot \frac{x_{M}}{x_{M_{c r}}} \cdot\left[1+\frac{k_{c} \cdot e x_{c}\left(x_{M}\right)}{k_{c h} \cdot e x_{c h}}\right]
\end{aligned}
$$

When the mine is completely exhausted its ore grade tends to the crustal concentration of the mineral $x_{M_{c r}}$ and the stored emergy in form of mineral reserves approaches zero because the quantity of extractable mineral becomes negligible. Based on Equation 24 the specific emergy of the depleted mine tends to the specific emergy of the Earth's crust $e m_{c r}$ :

$$
\lim _{x_{M} \rightarrow x_{M_{c r}}} e m_{\text {Mine }}\left(x_{M}\right)=e m_{c r}
$$

This shows that the depleted mine lost all its specific potentials that differentiate it from the rest of the surrounding land (where the average specific emergy is $e m_{c r}$ ). In terms of material hierarchy, this means that the mine is at the lowest position that it can ever reach in the hierarchy. Besides, during mining, the Earth in the mine has been removed to obtain the mineral. Hence, the total emergy of the empty mine tends to zero, and the post-mining ecosystem is out of balance because a part of the Earth's crust is missing. Additional work is required to restore the devastated land. It is possible to bulldoze the earth into the mine, but Odum specified (see Citation 8) that natural restored post-mining land is more valuable than artificially recovered land. Thus, the 
theoretical total emergy that Nature should invest to restore for itself the balance of the ecosystem $E m_{\text {Rest }}$ can be calculated by multiplying the removed mass of the mine $m_{r e m}$ with the specific emergy of the Earth's crust $e m_{c r}$.

$$
E m_{\text {Rest }}=m_{\text {rem }} \cdot e m_{c r}
$$

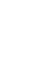
should be done to reestablish the post-mining land, because after restoration the former mine becomes an ordinary part of the Earth's crust without any particularly chemical or concentration potential, as the mined mineral has been replaced by ordinary earth. Besides pollution and other impacts of mining are not taken into account.

\section{Citation 8 (Environmental accounting)}

\footnotetext{
«Kangas (1983), evaluating the emergy of landforms and their colonization by ecosystems, found that irregular, post-mining lands, which had 20-40 yr of natural restoration through ecological succession and other processes, were more valuable than those lands that were bulldozed flat in well-intentioned restoration.» ( Odum (1996), p.123)

Figure 5 represents the life cycle of the mine, taking into account the restoration process after mining. It can be seen that this evaluation model distinguish three phases: a degraded, an enriched and a destroyed one where natural additional work is required for restoration. This shows that contrarily to the exergy analysis (see Figure 2) this emergy approach permits to evaluate the impact of mining and the work that should be done to restore the post-mining ecosystem.
} 


\section{Results}

\subsection{Proposition of Earth's crust emergy calculation}

The evolution and diversification of terrestrial minerals is a consequence of all the physical, chemical and biochemical processes trough which the Earth has passed since its creation four and a half billion years ago. The degree of mineral complexity of the planet is a result of local, regional and global selective processes enforced by Nature. The diversity and distribution of its terrestrial minerals reflect the intensity of the cyclic processes that have affected the Earth during its formation. Thus, to evaluate the emergy of the Earth's crust the historical context of mineral genesis should be studied. Or, it seems to be almost impossible to evaluate the energies involved in the Earth's crust formation with today's emergy scale because the Earth, at this time, was exposed to large sources of energy much more greater then present work of the geobiosphere. Indeed, the internal and external sources of heat were considerably more important (the radioactive heat generation was about five times higher than today (Valley et al., 2002)). Besides, the planet was subjected to heavy meteorite bombardments (Jørgensen et al., 2009) and extreme climate change (Hazen, 2010).

Recent studies had been performed to calculate the chemical exergy of the continental crust (Valero et al., 2012), the results may be used to determine the emergy of Earth's crust formation by using the appropriate transformity. Valero et al. (2011) emphasized that the abundance of concentrated chemical exergy is negligible compared to the whole Earth's crust since concentrated mineral resources (fuel and non-fuel origin) only represent $0.001 \%$ of the Earth's upper crust mass. And as their concentration exergies $e x_{c}$ (without adding unit exergy costs) are much more lower than their chemical exergies $e x_{c h}$ (Valero, 2008), the concentration potential of the Earth's crust can be neglected compared to its chemical potential, and its total exergy can be assimilated to its chemical exergy. Valero et al. (2012) proposed a thermodynamic evaluation tool which permits to calculate the chemical exergy wealth of the Earth's crust based on a framed model of the crust in its dispersed state, comprising about 300 of the most abun- 
dant minerals. The study is based on the crepuscular crust model developed previously by (Valero et al., 2011) to determine the chemical composition of the upper continental crust and on Szargut's Reference Evaluation Methodology (Szargut et al., 2005) to calculate the chemical exergy of any substance in the upper crust. The molar chemical exergy of the Earth's upper crust is estimated to be about ex $x_{c r}=3.63 \mathrm{E}+3 \mathrm{~J} / \mathrm{mol}$ which indicates an absolute chemical exergy of $E x_{c r}=2.53 \mathrm{E}+26 \mathrm{~J}$, for a molar weight of $M_{c r}=155.2 \mathrm{~g} / \mathrm{mol}$. The results are manifestly very rough and need further updates, but they inform well enough about the order of magnitude of the chemical wealth of the Earth crust.

To calculate the emergy of the Earth's crust $E m_{c r}$ basing on Valero's exergy analysis, the adequate transformity should be identified. Or, it is very difficult at this state of knowledge to evaluate precisely where the energies, involved in the Earth's crust evolution, are placed in the universal energy hierarchy. The emergy approach consider that sunlight, tidal energy and geothermal heat are the three main sources of energy that drove the complex processes of the geobiosphere and that these sources contributed to the Earth crust formation (Odum, 1996). Thus, the emergy $E m_{c r}$ can be expressed as follows:

$$
E m_{c r}=\alpha \cdot E m_{g e o b i o} \cdot t
$$

Where $E m_{\text {geobio }}$ is the annual emergy of the geobiosphere, $\alpha$ is the part of this emergy that generated the Earth crust formation and $t$ is the turnover time. In terms of exergy $E m_{c r}$ is then:

$$
E m_{c r}=\tau_{\text {geobio }} \cdot \alpha \cdot E x_{g e o b i o} \cdot t
$$

Where $E x_{\text {geobio }}$ is the annual exergy of the geobiosphere and $\tau_{\text {geobio }}$ is the average transformity of the geobiosphere. Hence, to calculate $E m_{c r}$ the values of $\alpha$ and $t$ should be determined as $E x_{\text {geobio }}$ and $\tau_{\text {geobio }}$ are known. Brown (2007), for example, considered 
that the entire annual exergy of the geobiosphere drove the Earth crust formation (i.e. $\alpha=1)$ and that the turnover time was about $2.5 \mathrm{E}+8 \mathrm{yrs}$.

Basing on this, it can be assumed that the term " $\alpha \cdot E x_{g e o b i o} \cdot t$ " reflects the pathway of the Earth crust formation and that the exergy of the Earth crust $E x_{c r}$ calculated by Valero et al. (2012) represents the result of this formation process:

$$
\alpha \cdot E x_{g e o b i o} \cdot t \approx E x_{c r}
$$

And thus, according to Equation $28 E m_{c r}$ can be expressed as follows:

$$
E m_{c r}=\tau_{g e o b i o} \cdot E x_{c r}
$$

For the numerical application the average transformity of the geobiosphere calculated by Brown and Ulgiati (2010) is used. Nevertheless, it should be underlined that the proposed evaluation method remains valid what ever value of $E m_{c r}$ or $\tau_{F}$ is chosen.

\section{Proposition 3 (Transformity of the Earth's crust)}

The transformity of Earth's crust formation $\tau_{F}$ is assumed to be equal to the average transformity of the geobiosphere $\tau_{\text {geobio }}$.

$$
\tau_{F} \stackrel{\text { def }}{=} \tau_{\text {geobio }}=4.2 \mathrm{seJ} / \mathrm{J}
$$

The emergy of the Earth's crust is obtained, then, by multiplying its exergy by the transformity, which gives an emergy of about $E m_{c r}=1.06 \mathrm{E}+27$ seJ, see Table 1.

$$
E m_{c r} \stackrel{\text { def }}{=} \tau_{F} \cdot E x_{c r}
$$

\subsection{Application to the main commercially used minerals}

Dispersed minerals are considered as co-products of the Earth's crust, thus absolute emergy of the dispersed mineral is equal to the absolute emergy of the Earth's crust. In this work, 42 of the main commercially used minerals has been studied. Table 2 
summarizes the chemical properties of these minerals (Valero et al., 2009). Table 3 displays the specific emergy of dispersed minerals, calculated by Equation 11. It can be seen that the results are consistent with the material's hierarchy, as scarce minerals like gold or silver have higher crustal specific emergies than abundant minerals like iron or nickel. In Table 4 the specific emergy of mineral reserves are calculated based on different approaches. The specific emergy $e m_{R}^{1}$ and $e m_{R}^{2}$ are both based on Equation 1, the first used a baseline of $1.62 \mathrm{E}+9 \mathrm{seJ} / \mathrm{g}$ proposed by Cohen et al. (2007) and the second a baseline of $1.35 \mathrm{E}+8 \mathrm{seJ} / \mathrm{g}$ updated by Brown (2007). The last column represents the specific emergy of mineral reserves calculated by the method proposed in the current work (see Equation 18), using the ore grade cutoff of the mine (OGC, see Table 4). It can be noted that the order of magnitude of $e m_{R}$ is mostly closer, to Brown's results $e m_{R}^{2}$ who used the specific emergy of the Earth's crust as baseline. Nevertheless, significant divergence for some minerals can be observed such as gold, tantalum or zinc. This can be explained by the fact that Brown (2007) used, similarly to this work, the average transformity of the geobiosphere $\tau_{\text {geobio }}$ to calculate the specific emergy of the Earth crust, see proposition 3. But choosing the latter as universal baseline for all minerals is not sufficient because this is not consistent with the material hierarchy and does not include the chemical potential of the mineral.

\subsection{Application to the emergy decrease of mineral reserves: Case of some Australian mineral reserves}

Since the late 18th century several mining booms occurred in Australia. In this section the emergy decrease of some Australian mineral reserves such as gold, copper, nickel, silver, lead, zinc and iron has been studied, the required data has been taken from Valero (2008). Table 5 represents the main characteristics of these reserves since their discovery until now. The initial specific emergies $e m_{R}\left(x_{M}^{\circ}\right)$ and the current specific emergy $\mathrm{em}_{R}\left(x_{M}\right)$ have been calculated by using Equation 18 and respectively the initial and current ore grades $x_{M}^{\circ}$ and $x_{M}$, listed in Table 5. The last column of this table represents, in percent, the specific emergy decrease of mineral reserves $D$. The results 
reveal that, over the past century, especially gold, copper and lead reserves suffered from a drastic decrease by about $30 \%$ in specific emergy, due to the fact that their ore grades have notably declined. Whereas, in spite of the huge quantities of iron that are mined every year the ore grade of iron reserve little changed due to the abundance of iron rich deposits in Australia and thus the specific emergy of iron reserve remains almost constant.

\subsection{Application to the land degradation of ore deposits: Case of US copper mines}

The aim of this section is to evaluate the emergy loss of US copper deposits when all their reserves are exhausted and to estimate the minimum emergy that Nature should invest to replace the extracted mineral from the mines. In order to use the methodology proposed in Equation 24 and Equation 26, it is assumed that US copper reserves represent a huge mine with an initial ore grade $x_{\text {Copper }}^{\circ}$ and an initial mineral content $m_{\text {Copper }}^{\circ}$. Because of data unavailability, the mining activity before the year 1900 has been neglected. The initial copper mass $m_{\text {Copper }}^{\circ}$ has been determined by cumulating the primary copper production from 1900 to 2001, adding them the reserve base of the year 2001 (USGS, 2011). This permits to obtain an ore mass of about $m_{\text {Copper }}^{\circ}=1.84 \mathrm{E}+11 \mathrm{~kg}$, the initial ore grade of copper in 1900 was about $2 \%$ (Valero, 2008). The calculation reveals that the emergy $E m_{\text {Mine }}\left(x_{\text {Copper }}^{\circ}\right)$ lost irreversibly by the ecosystem when all the mineral is extracted is about 7.26 E+20 seJ and that the emergy $E m_{\text {Rest }}$ required to replace the mined mineral by ordinary earth is about $1.81 \mathrm{E}+16$ seJ (it is considered that only the mineral reserve would be removed from the mine i.e. $\left.m_{\text {rem }}=m_{\text {Copper }}^{\circ}\right)$. The results are summarized in Table 6.

\section{Conclusion}

1. Emergy and exergy assessment tools have been combined to evaluate the environmental impact of mining, considering only the natural exergy of the mineral.

2. Every group of dispersed mineral is assumed to be a co-product of the Earth's crust. The specific emergy of about 40 main commercially used minerals have 
been calculated, respecting the material hierarchy as the specific emergy rise with scarcity.

3. An evaluation model was proposed that permits to calculate the specific emergy of mineral reserves based on the chemical and concentration exergy of the mineral, its abundance and concentration in the mine. The application to some Australian mineral reserves shows that the specific emergy of the reserve decreases with its ore grade. Theoretically, when all the reserve is exhausted its specific emergy tends to the crustal specific emergy of the mineral $e m_{M}\left(x_{M_{c r}}\right)$, representing the lowest position that the reserve can ever reach in the material hierarchy.

4. To make the methodology realized by Cohen et al. (2007) and Brown (2007) consistent with the material hierarchy, it is proposed to use instead of an universal baseline the crustal specific emergy of the mineral $e m_{M}\left(x_{M_{c r}}\right)$ and as enrichment factor the ratio between the specific exergy of the concentrated ore reserve $e x_{M}\left(x_{M}^{\circ}\right)$ and the crustal specific exergy of the mineral $e x_{M}\left(x_{M_{c r}}\right)$ (see Proposition $1)$.

5. To assess the impact of mining on the ecosystem, a methodology is introduced that permits to quantify the theoretical minimum emergy that Nature should invest to restore the post-mining land. The application to the US copper mines reveals that the ecosystem will loose about $7.26 \mathrm{E}+20$ seJ when all the copper reserves have been extracted and that Nature should invest at least about 1.81 $\mathrm{E}+16$ seJ to restore the post-mining land.

6. Although different methods could be envisaged to calculate the emergy of the Earth's crust, the proposed evaluation model remains valid whatever numerical value of the latter is chosen 
591

592

593

\section{Appendix}

The emergy approach consider that sunlight, tidal energy and geothermal heat are the three main sources of exergy that drive the complex processes of the geobiosphere Odum (1996). The annual global emergy budget is calculated by multiplying the annual exergy flows of these sources by their transformities, as shown in Table 7 . Admitting that the transformity of solar is equal to one, the transformities of tidal and geothermal heat has been calculated by establishing two equations: one expressing the exergy contributions to geothermal heat and the other the exergy contributions to ocean geopotential. The average transformity of the geobiosphere $\tau_{\text {geobio }}$ is then the ratio between the annual emergy flow of the geobiosphere $E m_{\text {geobio }}$ and its exergy flow $E x_{\text {geobio }}$, see Equation 32. All the unit emergy values used in this work are based on the annual emergy budget of the geobiosphere calculated by Brown and Ulgiati (2010), see Table 7.

$$
\tau_{\text {geobio }}=\frac{E m_{\text {geobio }}}{E x_{\text {geobio }}}
$$




\section{List of Figures}

605

606

Process of raw material production (Valero and Valero, 2005) . . . . .

2 Theoretical formation process of the mineral, from the reference environment to the conditions in the mine . . . . . . . . . . 38

3 Specific exergy of an ore deposit at different evolution stages . . . . . . 39

4 Theoretical evolution process of mineral reserves . . . . . . . . . . . 40

5 Total emergy of a mineral reserve during its life cycle with restoration process ................................ 41 
612

${ }_{613} 1$ Thermodynamic and emergetic properties of the Earth's upper crust . . 42

${ }_{614} 2$ Chemical properties of the main commercially used minerals . . . . . 45

615

616

617

618

619

620

\section{List of Tables}

3 Crustal specific emergy of the main commercially used minerals _ . . . 47

4 Specific emergies of mineral reserves at their $O G C$ calculated by different approaches .............................. 50

$5 \quad$ Characteristics of Australians mineral reserves . . . . . . . . . . . 51

$6 \quad$ Emergy loss and mine restoration of US copper reserves . . . . . . . . . 52

$7 \quad$ Global emergy budget of the geobiosphere (Brown and Ulgiati, 2010) . 53 
621

\section{Nomenclature}

\section{Acronyms}

$O G C$ Ore grade cutoff [-]

\section{Greek Symbols}

$\lambda \quad$ Ratio between the molar mass of mineral $M_{M}$ and the average molar mass of the mixture $M_{t o t}, \lambda_{M}=\frac{M_{t o t}}{M_{M}}[-]$

$\alpha \quad$ Part of the emergy of the geobiosphere that contributed to the Earth crust formation

$\tau \quad$ Transformity

\section{Roman Symbols}

$B \quad$ Baseline $[\mathrm{seJ} / \mathrm{g}]$

$\Delta g_{f} \quad$ Specific Gibbs free energy of mineral formation $[\mathrm{J} / \mathrm{g}]$

$E R \quad$ Enrichment factor, $E R=\frac{O G C}{x_{M_{c r}}}[-]$

Em Absolute emergy [seJ]

em Specific emergy $[\mathrm{seJ} / \mathrm{g}]$

Ex Absolute exergy [J]

ex $\quad$ Specific exergy $[\mathrm{J} / \mathrm{mol}]$

$k \quad$ Unit exergy replacement cost [-]

$M \quad$ Molar mass $[\mathrm{g} / \mathrm{mol}]$

$m$ mass $[\mathrm{g}]$

$R \quad$ Universal gas constant $[8.314 \mathrm{~J} / \mathrm{mol} \mathrm{K}]$ 
${ }_{642} \quad T^{\circ} \quad$ Standard ambient temperature [298.15 K]

${ }^{643} \quad x \quad$ Massic fraction $[\mathrm{g} / \mathrm{g}]$

${ }_{644} y \quad$ Molar fraction $[\mathrm{mol} / \mathrm{mol}]$

${ }_{645}$ Superscripts

${ }_{646} \circ$ Initial conditions

${ }_{647} \quad r \quad$ Real exergy cost

648 Subscripts

${ }_{649} \quad c \quad$ Concentration

${ }_{650} \quad c h$ Chemical

${ }_{651} \mathrm{cr} \quad$ Crust

${ }_{652} \quad F \quad$ Earth crust formation

${ }_{653}$ geobio Geobiosphere

${ }_{654} \quad i \quad$ Component $i$

${ }_{655} M \quad$ Mineral

${ }_{656}$ Mine Mine

${ }_{657} \quad R \quad$ Mineral reserve

${ }_{658}$ rem Removed

${ }_{659}$ Rest Restoration 


\section{References}

Brown, M.T., 2007. Material Cycles and Energy Hierarchy. Online under:http://www.cep.ees.ufl.edu/emergy/resources/presentations.shtml, 2013.

Brown, M.T., Ulgiati, S., 2004. Energy quality, emergy, and transformity: H.T. Odum's contributions to quantifying and understanding systems. Ecological Modelling 178, $201-213$.

Brown, M.T., Ulgiati, S., 2010. Updated evaluation of exergy and emergy driving the geobiosphere: A review and refinement of the emergy baseline. Ecological Modelling 221, 2501-2508.

Burnett, M.S., 1981. A methodology for assessing net energy and abundance of energy resources. Energy and Ecological Modelling , 703-710.

Cohen, M.J., Sweeny, S., Brown, M.T., $2007 . \quad$ Computing the Unit Emergy Value of Crustal elements, in: Proceedings of the fourth Biennal Emergy, Center for Environmental Policy, University of Florida, Gainsville, Florida. pp. 16.1-16.12. Online under: http://www.cep.ees.ufl.edu/emergy/conferences/ERC04_2006/proceedings.shtml.

Garrels, R.M., Mackenzie, F.T., Hunt, C., 1975. Chemical cycles and the Global Environment. Wiliam Kaufmann, Los Altos, California.

Hazen, R., 2010. The evolution of minerals. Scientific American 303, 58-65.

Hazen, R., Ferry, J., 2010. Mineral evolution: Mineralogy in the fourth dimension. Elements 6, 9-12.

Jorgensen, S., 2006. Eco-Exergy as Sustainability. WIT Press, UK.

Jørgensen, U.G., Appel, P.W.U., Hatsukawa, Y., Frei, R., Oshima, M., Toh, Y., Kimura, A., 2009. The Earth-Moon system during the late heavy bombardement period Geochemical support for impacts dominated by comets. Icarus 204, 368-380. 
Martinez, A., Valero, A., Valero-Delgado, A., Arauzo, I., 2007. Comparing the Earth's Mineral Wealth from the Point of View of Emergy and Exergetic Cost Analysis, in: Proceedings of the fourth Biennal Emergy, Center for Environmental Policy, University of Florida, Gainsville, Florida. pp. 17.1-17.14. Online under: http://www.cep.ees.ufl.edu/emergy/conferences/ERC04_2006/proceedings.shtml.

McCoy, T.J., 2010. Minerological evolution of meteorites. Elements 6, 19-23.

Odum, H.T., 1996. Environmental Accounting: Emergy and Environmental Desicion Making. John Wiley \& Sons, New York.

Odum, H.T., 2000a. An Energy Hierarchy Law For Biogeochemical Cycles, in: Proceedings of the first Biennal Emergy, Center for Environmental Policy, University of Florida, Gainsville, Florida. pp. 235-248. Online under: http://www.cep.ees.ufl.edu/emergy/conferences/ERC01_1999/proceedings.shtml.

Odum, H.T., 2000b. Handbook of Emergy Evaluation Folio 2: Emergy of Global Processes. Center for Environmental Policy, University of Florida. Online under: http://www.cep.ees.ufl.edu/emergy/documents/folios/Folio_02.pdf.

Riekert, L., 1974. The efficiency of energy utilization in chemical processes. Chem. Eng. Sci 29, 1613-1620.

Sciubba, E., 2010. On the Second-Law inconsistency of emergy analysis. Energy 1, 11.

Sverjensky, D.A., 2010. The Great Oxydation Event and mineral diversification. Elements $6,31-36$.

Szargut, J., 1989. Chemical exergies of the elements. Applied Energy 32, 269-286.

Szargut, J., Valero, A., Stanek, W., D, A.V., 2005. Towards an international legal reference environment, in: Proceedings of ECOS 2005, Trondheim, Norway. pp. 409420. 
Szargut, J., Ziebik, A., Stanek, W., 2002. Depletion of the non-renewable natural exergy resources as a measure of the ecological cost. Energy Conversion and Management, $1149-1163$.

USGS, 2011. Historical statistics for mineral and material commodities in the United States. Report. US Geological Survey. Online under: http://minerals.usgs.gov/ds/2005/140/.

Valero, A., 1998. Thermoeconomics as a conceptual basis for energy-ecological analysis, in: Ulgiati, S. (Ed.), Advances in Energy Studies. Energy Flows in Ecology and Economy, Musis, Roma. pp. 415-444.

Valero, A., 2008. Exergy evolution of the mineral capital on earth. Ph.D. thesis. University of Zaragoza. Zaragoza, Spain.

Valero, A., Botero, E., Valero, A., 2009. Global Exergy Accounting of Natural Resources, in: EOLLS Encyclopedia of life support systems (Ed.), Exergy, Energy System Analysis and Optimization, pp. 409-420.

Valero, A., Ranz, L., Botero, E., 2002a. Exergetic Evaluation of Natural Mineral Capital (1) Reference Environment Methodology, in: Tsatsaronis, G., Moran, M., Cziesla, F., Bruckner, T. (Eds.), ECOS 2002, Berlin. pp. 54-61.

Valero, A., Ranz, L., Botero, E., 2002b. Exergetic evaluation ofNatural Mineral Capital (2). Application of the methodology to current world reserves., in: Tsatsaronis, G., Moran, M., Cziesla, F., Bruckner, T. (Eds.), ECOS 2002, Berlin. pp. 62-68.

Valero, A., Valero, A., 2005. The crepuscular planet. part ii: A model for the exhausted continental crus, in: Proceedings of ECOS 2005, Trondheim, Norway. pp. 409-420.

Valero, A., Valero, A., Arauzo, I., 2008. Evolution of the decrease in mineral exergy throughout the 20th century. the case of copper in the us. Energy 33, 107-115. 
733 Valero, A., Valero, A., Gómez, J.B., 2011. The crepuscular planet. Amodel for the 734 exhausted continental crust. Energy 36(1), 694-707.

735 Valero, A., Valero, A., Veillard, P., 2012. The thermodynamic properties of the upper 736 continental crust:Exergy, Gibbs free energy and enthalpy. Energy 41, 121-127.

${ }_{737}$ Valley, J.W., Peck, W.H., King, E.M., Wilde, S.A., 2002. A cool early Earth. Geology $738 \quad 4,351-354$. 


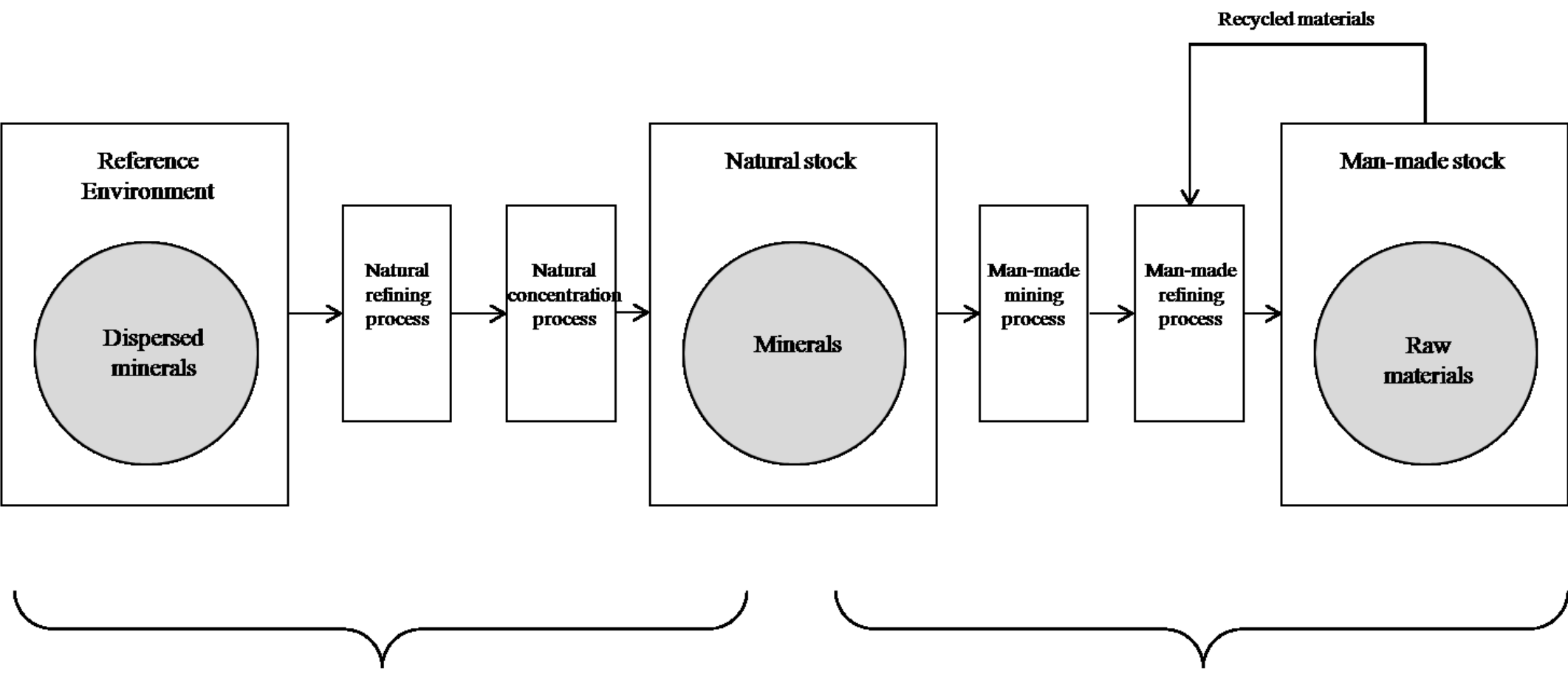




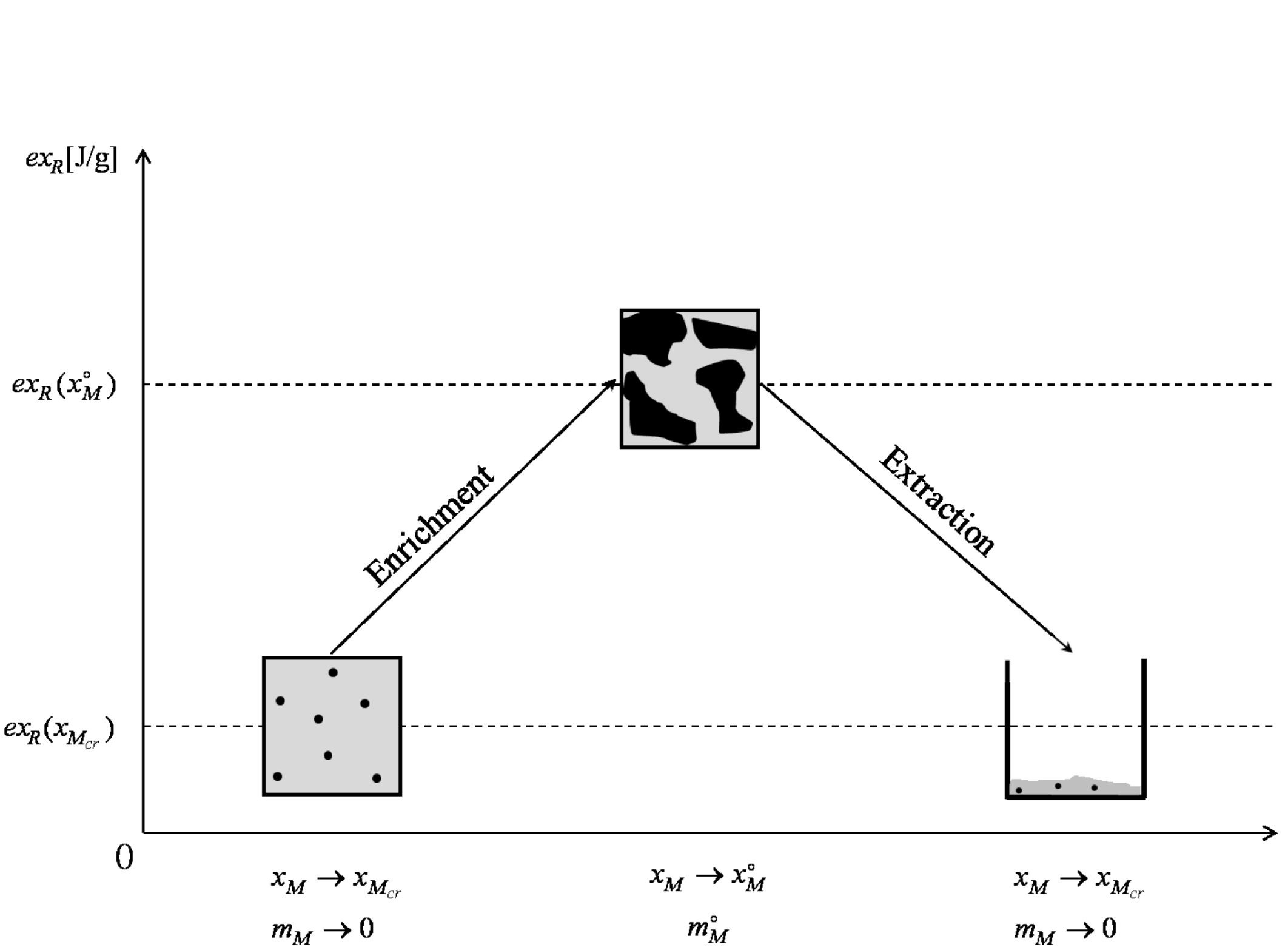

\section{Figure3}

.
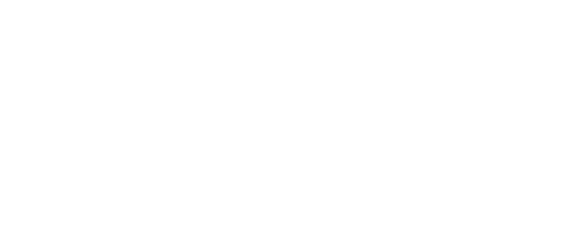


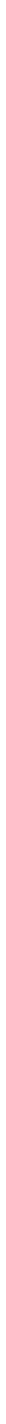

$R$ : Mineral reserve

R.S. : Reference Substances$$
\text { ( }
$$ 
$E m_{\text {Mine }}[\mathrm{seJ}] \uparrow$

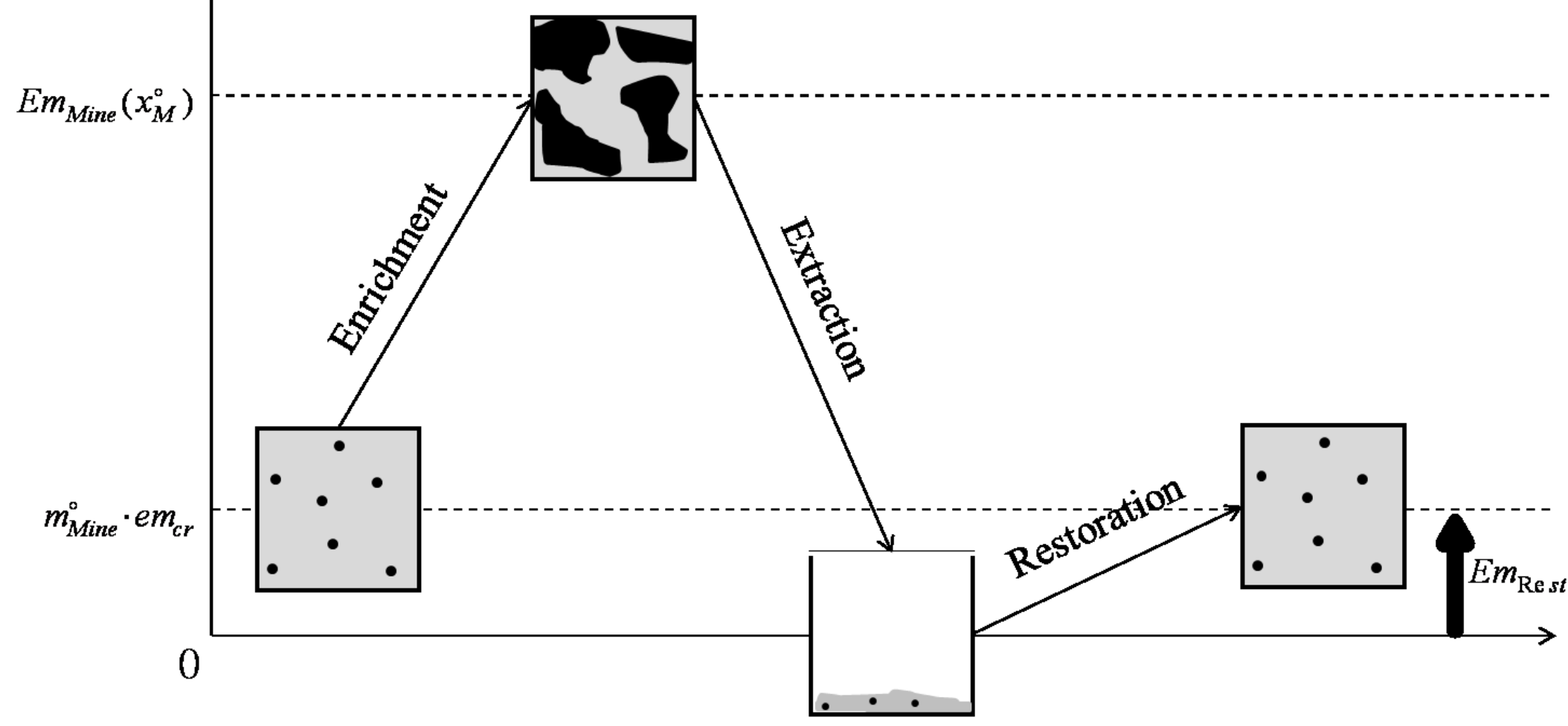

$$
\begin{array}{lccc}
x_{M} \rightarrow x_{M_{c r}} & x_{M} \rightarrow x_{M}^{\circ} & x_{M} \rightarrow x_{M_{c r}} & x_{M} \rightarrow x_{M_{c r}} \\
m_{\text {Mine }}^{\circ} & m_{\text {Mine }}^{\circ} & m_{\text {Mine }} \rightarrow 0 & m_{\text {Mine }}^{\circ}
\end{array}
$$




\begin{tabular}{llllll}
\hline$m_{c r}[\mathrm{~kg}]$ & $M_{c r}[\mathrm{~g} / \mathrm{mol}]$ & $e x_{c r}[\mathrm{~J} / \mathrm{mol}]$ & $E x_{c r}[\mathrm{~J}]$ & $\tau_{F}[\mathrm{seJ} / \mathrm{J}]$ & $E m_{c r}[\mathrm{seJ}]$ \\
\hline $1.08 \mathrm{E}+22$ & 155.2 & $3.63 \mathrm{E}+3$ & $2.53 \mathrm{E}+26$ & 4.2 & $1.06 \mathrm{E}+27$ \\
\hline
\end{tabular}

Table 1: Thermodynamic and emergetic properties of the Earth's upper crust 
Chemical properties of the main commercially used mineral

\begin{tabular}{|c|c|c|c|c|c|c|c|c|}
\hline Name & Chemical Formula & $M_{M}[\mathrm{~g} / \mathrm{mol}]$ & $x_{M_{c r}} \mathrm{E}-6$ & $O G C \mathrm{E}-2$ & $E R_{R}$ & $k_{c M}$ & $k_{c h M}$ & $e x_{c h M}[\mathrm{~kJ} / \mathrm{m} \Theta]$ \\
\hline Aluminium & $\mathrm{Al}_{2} \mathrm{O}_{3}$ & 102 & $8.00 \mathrm{E}+04$ & $1.70 \mathrm{E}+01$ & $2.10 \mathrm{E}+00$ & $3.96 \mathrm{E}+02$ & 1 & $3.49 \mathrm{E}+01 \supseteqq$ \\
\hline Antimony & $S b_{2} S_{3}$ & 339.7 & $2.00 \mathrm{E}-01$ & $1.00 \mathrm{E}+01$ & $5.00 \mathrm{E}+05$ & $2.84 \mathrm{E}+01$ & 10 & $2.52 \mathrm{E}+03$ \\
\hline Arsenic & $F e A s S$ & 162.8 & $1.50 \mathrm{E}+00$ & $2.00 \mathrm{E}+00$ & $1.33 \mathrm{E}+04$ & $7.99 \mathrm{E}+01$ & 10 & $1.43 \mathrm{E}+03$ \\
\hline Barium & $\mathrm{BaSO}_{4}$ & - & $5.50 \mathrm{E}+02$ & $5.80 \mathrm{E}+00$ & $1.06 \mathrm{E}+02$ & NA & 1 & $=$ \\
\hline Beryllium & $6 \mathrm{SiO}_{2} \cdot \mathrm{Al}_{2} \mathrm{O}_{3} \cdot 3 \mathrm{BeO}$ & 537.6 & $3.00 \mathrm{E}+00$ & $4.00 \mathrm{E}+00$ & $1.33 \mathrm{E}+04$ & $1.12 \mathrm{E}+02$ & 1 & $6.58 \mathrm{E}+01$ \\
\hline Bismuth & $B i_{2} S_{3}$ & 514.2 & $1.27 \mathrm{E}-01$ & $5.00 \mathrm{E}+00$ & $3.94 \mathrm{E}+05$ & $8.98 \mathrm{E}+01$ & 10 & $2.23 \mathrm{E}+03$ \\
\hline Cadmium & $C d S$ & 144.5 & $9.80 \mathrm{E}-02$ & $4.00 \mathrm{E}-01$ & $4.08 \mathrm{E}+04$ & $8.04 \mathrm{E}+02$ & 10 & $7.44 \mathrm{E}+02$ \\
\hline Cesium & $\mathrm{CsCl}$ & - & $3.70 \mathrm{E}+00$ & $2.00 \mathrm{E}+01$ & $5.41 \mathrm{E}+04$ & NA & 1 & - \\
\hline Chrome & $\mathrm{FeCr}_{2} \mathrm{O}_{4}$ & 223.8 & $3.50 \mathrm{E}+01$ & $2.30 \mathrm{E}+01$ & $6.57 \mathrm{E}+03$ & $3.67 \mathrm{E}+01$ & 1 & $1.95 \mathrm{E}+02$ \\
\hline Cobalt & $\mathrm{CoS}_{2}$ & 123.1 & $1.00 \mathrm{E}+01$ & $2.00 \mathrm{E}-01$ & $2.00 \mathrm{E}+02$ & $1.26 \mathrm{E}+03$ & 10 & $1.39 \mathrm{E}+03$ \\
\hline Copper & $\mathrm{CuFeS} \mathrm{S}_{2}$ & 183.5 & $2.50 \mathrm{E}+01$ & $5.00 \mathrm{E}-01$ & $2.00 \mathrm{E}+02$ & $3.86 \mathrm{E}+02$ & 10 & $1.53 \mathrm{E}+03$ \\
\hline Fluoride & $\mathrm{CaF}_{2}$ & 78.1 & $6.50 \mathrm{E}+02$ & $1.00 \mathrm{E}-01$ & $1.50 \mathrm{E}+00$ & $1.70 \mathrm{E}+00$ & 1 & $5.03 \mathrm{E}+01$ \\
\hline Gallium & $\mathrm{Ga}(\mathrm{OH})_{3}$ & - & $1.70 \mathrm{E}+01$ & $1.00 \mathrm{E}-02$ & $5.90 \mathrm{E}+00$ & - & 1 & - \\
\hline Germanium & $\mathrm{GeO}_{2}$ & - & $1.60 \mathrm{E}+00$ & $6.00 \mathrm{E}+00$ & $3.75 \mathrm{E}+04$ & - & 1 & - \\
\hline Gold & $A u$ & 197 & $1.80 \mathrm{E}-03$ & $1.50 \mathrm{E}-03$ & $8.33 \mathrm{E}+03$ & $4.09 \mathrm{E}+05$ & 1 & $5.99 \mathrm{E}+01$ \\
\hline Hafnium & $\mathrm{HfO}_{2}$ & - & $5.80 \mathrm{E}+00$ & 4.00E-02 & $6.90 \mathrm{E}+01$ & - & 1 & - \\
\hline Indium & $\operatorname{In} S$ & 146.9 & $5.00 \mathrm{E}-02$ & $1.00 \mathrm{E}-02$ & $2.00 \mathrm{E}+03$ & $-4.39 \mathrm{E}+01$ & 10 & $9.13 \mathrm{E}+02$ \\
\hline Iron & $\mathrm{Fe}_{2} \mathrm{O}_{3}$ & 159.7 & $3.50 \mathrm{E}+04$ & $5.00 \mathrm{E}+01$ & $1.43 \mathrm{E}+01$ & $4.40 \mathrm{E}+01$ & 1 & $1.64 \mathrm{E}+01$ \\
\hline Lead & $P b S$ & 239.3 & $2.00 \mathrm{E}+01$ & $4.00 \mathrm{E}+00$ & $2.00 \mathrm{E}+03$ & $2.12 \mathrm{E}+02$ & 10 & $7.41 \mathrm{E}+02$ \\
\hline Lithium & $\mathrm{LiAlSi}_{2} \mathrm{O}_{6}$ & 186.1 & $2.00 \mathrm{E}+01$ & $3.00 \mathrm{E}+00$ & $1.50 \mathrm{E}+03$ & $1.58 \mathrm{E}+02$ & 1 & $2.87 \mathrm{E}+01$ \\
\hline Magnesium & $M g C l_{2}$ & 95.2 & $1.33 \mathrm{E}+04$ & $1.00 \mathrm{E}-01$ & $1.00 \mathrm{E}-01$ & $1.00 \mathrm{E}+00$ & 1 & $1.61 \mathrm{E}+02$ \\
\hline Manganese & $\mathrm{MnO}_{2}$ & 86.9 & $6.00 \mathrm{E}+02$ & $2.50 \mathrm{E}+01$ & $4.17 \mathrm{E}+02$ & $2.84 \mathrm{E}+02$ & 1 & $3.49 \mathrm{E}+01$ \\
\hline Mercury & $H g S$ & 232.7 & $8.00 \mathrm{E}-02$ & $1.00 \mathrm{E}-01$ & $1.25 \mathrm{E}+04$ & $1.71 \mathrm{E}+03$ & 10 & $6.79 \mathrm{E}+02$ \\
\hline Molybdenum & $M o S_{2}$ & 160.1 & $1.50 \mathrm{E}+00$ & $3.00 \mathrm{E}-01$ & $2.27 \mathrm{E}+03$ & $9.47 \mathrm{E}+02$ & 1 & $1.72 \mathrm{E}+03$ \\
\hline
\end{tabular}




\begin{tabular}{|c|c|c|c|c|c|c|c|c|}
\hline Name & Chemical Formula & $M_{M}[\mathrm{~g} / \mathrm{mol}]$ & $x_{M_{c r}} \mathrm{E}-6$ & $O G C \mathrm{E}-2$ & $E R_{R}$ & $k_{c M}$ & $k_{c h M}$ & $e x_{c h M}\left[\mathrm{~kJ} / \mathrm{m}_{\overline{\mathbf{Q}}}\right]$ \\
\hline Nickel & $N i S$ & 90.7 & $2.00 \mathrm{E}+01$ & $9.00 \mathrm{E}-01$ & $4.50 \mathrm{E}+02$ & $3.37 \mathrm{E}+02$ & 10 & $7.66 \mathrm{E}+02 \quad$ \\
\hline Niobium & $\mathrm{Nb}_{2} \mathrm{O}_{5}$ & - & $2.50 \mathrm{E}+01$ & $5.00 \mathrm{E}-01$ & $1.88 \mathrm{E}+02$ & NA & 1 & $\supseteqq$ \\
\hline Phosphorous & $\mathrm{P}_{2} \mathrm{O}_{5}$ & 142 & $7.00 \mathrm{E}+02$ & $1.48 \mathrm{E}+01$ & $2.11 \mathrm{E}+02$ & $4.39 \mathrm{E}+01$ & 1 & $3.59 \mathrm{E}+02$ \\
\hline Platinum & $\operatorname{PtS}$ & - & $1.00 \mathrm{E}-02$ & $1.95 \mathrm{E}-03$ & $1.95 \mathrm{E}+03$ & NA & 1 & 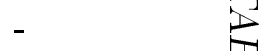 \\
\hline Potassium & $K C l$ & 74.56 & $2.80 \mathrm{E}+04$ & $1.50 \mathrm{E}+01$ & $5.77 \mathrm{E}+04$ & $3.86 \mathrm{E}+01$ & 1 & $1.96 \mathrm{E}+01$ \\
\hline Rhenium & $\operatorname{Re} S_{2}$ & 250.3 & $4.00 \mathrm{E}-04$ & $3.00 \mathrm{E}-01$ & $3.00 \mathrm{E}+06$ & $1.94 \mathrm{E}+03$ & 10 & $1.62 \mathrm{E}+03$ \\
\hline Selenium & $\mathrm{SeO}_{2}$ & - & $5.00 \mathrm{E}+01$ & $2.50 \mathrm{E}-04$ & $2.50 \mathrm{E}+01$ & NA & 1 & - \\
\hline Silicon & $\mathrm{SiO}_{2}$ & 60.1 & $3.08 \mathrm{E}+05$ & $4.00 \mathrm{E}+01$ & $1.30 \mathrm{E}+00$ & $1.89 \mathrm{E}+00$ & 1 & $8.20 \mathrm{E}-01$ \\
\hline Silver & $\mathrm{Ag}_{2} \mathrm{~S}$ & 247.8 & $5.00 \mathrm{E}-02$ & $1.00 \mathrm{E}-02$ & $2.00 \mathrm{E}+03$ & $7.05 \mathrm{E}+03$ & 10 & $7.06 \mathrm{E}+02$ \\
\hline Sodium & $\mathrm{NaCl}$ & 58.4 & $2.90 \mathrm{E}+04$ & $2.00 \mathrm{E}+01$ & $6.90 \mathrm{E}+00$ & $3.81 \mathrm{E}+01$ & 1 & $1.44 \mathrm{E}+01$ \\
\hline Tantalum & $T a_{2} O_{5}$ & 441.1 & $2.20 \mathrm{E}+00$ & $1.00 \mathrm{E}-01$ & $2.50 \mathrm{E}+02$ & $1.25 \mathrm{E}+04$ & 1 & $4.56 \mathrm{E}+01$ \\
\hline Tellurium & $\mathrm{TeO}_{2}$ & - & $1.00 \mathrm{E}-03$ & $1.00 \mathrm{E}-04$ & $1.00 \mathrm{E}+02$ & NA & 1 & - \\
\hline Tin & $\mathrm{SnO}_{2}$ & 150.7 & $5.50 \mathrm{E}+00$ & 4.00E-01 & $6.36 \mathrm{E}+02$ & $1.49 \mathrm{E}+03$ & 1 & $4.26 \mathrm{E}+01$ \\
\hline Titanium & $\mathrm{FeTiO}_{3}$ & 151.7 & $3.00 \mathrm{E}+03$ & $1.00 \mathrm{E}+01$ & $3.33 \mathrm{E}+01$ & $3.48 \mathrm{E}+02$ & 1 & $1.30 \mathrm{E}+02$ \\
\hline Tungsten & $\mathrm{CaWO}_{4}$ & 288 & $2.00 \mathrm{E}+00$ & $6.00 \mathrm{E}-01$ & $3.00 \mathrm{E}+03$ & $3.10 \mathrm{E}+03$ & 1 & $7.21 \mathrm{E}+01$ \\
\hline Vanadium & $\mathrm{V}_{2} \mathrm{O}_{5}$ & 182 & $6.00 \mathrm{E}+01$ & 6.00E-01 & $4.29 \mathrm{E}+01$ & $5.72 \mathrm{E}+02$ & 1 & $3.23 \mathrm{E}+01$ \\
\hline Zinc & $Z n S$ & 97.4 & $7.10 \mathrm{E}+01$ & $3.50 \mathrm{E}+00$ & $4.93 \mathrm{E}+02$ & $6.28 \mathrm{E}+01$ & 10 & $7.44 \mathrm{E}+02$ \\
\hline Zirconium & $\mathrm{ZrSiO}_{4}$ & 183.3 & $1.90 \mathrm{E}+02$ & $2.00 \mathrm{E}+00$ & $1.05 \mathrm{E}+02$ & $7.74 \mathrm{E}+03$ & 1 & $3.08 \mathrm{E}+01$ \\
\hline
\end{tabular}

Table 2: Chemical properties of the main commercially used minerals 


\begin{tabular}{|c|c|c|}
\hline \multicolumn{3}{|c|}{ Dispersed specific emergy of the main commercially used mineral } \\
\hline Name & Chemical Formula & $e m_{M}\left(x_{M_{c r}}\right)[\mathrm{seJ} / \mathrm{g}]$ \\
\hline Aluminium & $\mathrm{Al}_{2} \mathrm{O}_{3}$ & $1.23 \mathrm{E}+03$ \\
\hline Antimony & $S b_{2} S_{3}$ & $4.92 \mathrm{E}+08$ \\
\hline Arsenic & FeAsS & $6.56 \mathrm{E}+07$ \\
\hline Barium & $\mathrm{BaSO}_{4}$ & $1.79 \mathrm{E}+05$ \\
\hline Beryllium & $6 \mathrm{SiO}_{2} \cdot \mathrm{Al}_{2} \mathrm{O}_{3} \cdot 3 \mathrm{BeO}$ & $3.28 \mathrm{E}+07$ \\
\hline Bismuth & $\mathrm{Bi}_{2} \mathrm{~S}_{3}$ & $7.75 \mathrm{E}+08$ \\
\hline Cadmium & $C d S$ & $1.00 \mathrm{E}+09$ \\
\hline Cesium & $C s C l$ & $2.66 \mathrm{E}+07$ \\
\hline Chrome & $\mathrm{FeCr}{ }_{2} \mathrm{O}_{4}$ & $2.81 \mathrm{E}+06$ \\
\hline Cobalt & $\mathrm{CoS}_{2}$ & $9.84 \mathrm{E}+06$ \\
\hline Copper & CuFeS $S_{2}$ & $3.94 \mathrm{E}+06$ \\
\hline Fluoride & $\mathrm{CaF}_{2}$ & $1.51 \mathrm{E}+05$ \\
\hline Gallium & $\mathrm{Ga}(\mathrm{OH})_{3}$ & $5.79 \mathrm{E}+06$ \\
\hline Germanium & $\mathrm{GeO}_{2}$ & $6.15 \mathrm{E}+07$ \\
\hline Gold & $A u$ & $5.47 \mathrm{E}+10$ \\
\hline Hafnium & $\mathrm{HfO}_{2}$ & $1.70 \mathrm{E}+07$ \\
\hline Indium & $\operatorname{In} S$ & $1.97 \mathrm{E}+09$ \\
\hline Iron & $\mathrm{Fe}_{2} \mathrm{O}_{3}$ & $2.81 \mathrm{E}+03$ \\
\hline Lead & $\mathrm{PbS}$ & $4.92 \mathrm{E}+06$ \\
\hline Lithium & $\mathrm{LiAlSi}_{2} \mathrm{O}_{6}$ & $4.92 \mathrm{E}+06$ \\
\hline Magnesium & $\mathrm{MgCl2}$ & $7.40 \mathrm{E}+03$ \\
\hline Manganese & $\mathrm{MnO}_{2}$ & $1.64 \mathrm{E}+05$ \\
\hline Mercury & $H g S$ & $1.23 \mathrm{E}+09$ \\
\hline Molybdenum & MoS2 & $6.56 \mathrm{E}+07$ \\
\hline Nickel & $N i S$ & $4.92 \mathrm{E}+06$ \\
\hline Niobium & $\mathrm{Nb}_{2} \mathrm{O}_{5}$ & $3.94 \mathrm{E}+06$ \\
\hline Phosphorous & $\mathrm{P}_{2} \mathrm{O}_{5}$ & $1.41 \mathrm{E}+05$ \\
\hline Platinum & $P t S$ & $9.84 \mathrm{E}+09$ \\
\hline Potassium & $K C l$ & $3.51 \mathrm{E}+03$ \\
\hline Rhenium & $\operatorname{Re} S_{2}$ & $2.46 \mathrm{E}+11$ \\
\hline Selenium & $\mathrm{SeO}_{2}$ & $1.97 \mathrm{E}+06$ \\
\hline Silicon & $\mathrm{SiO}_{2}$ & $3.19 \mathrm{E}+02$ \\
\hline Silver & $\mathrm{Ag}_{2} \mathrm{~S}$ & $1.97 \mathrm{E}+09$ \\
\hline Sodium & $\mathrm{NaCl}$ & $3.39 \mathrm{E}+03$ \\
\hline Tantalum & $\mathrm{Ta}_{2} \mathrm{O}_{5}$ & $4.47 \mathrm{E}+07$ \\
\hline Tellurium & $\mathrm{TeO}_{2}$ & $9.84 \mathrm{E}+10$ \\
\hline Tin & $\mathrm{SnO}_{2}$ & $1.79 \mathrm{E}+07$ \\
\hline Titanium & $\mathrm{FeTiO}_{3}$ & $3.28 \mathrm{E}+04$ \\
\hline Tungsten & $\mathrm{CaWO}_{4}$ & $4.92 \mathrm{E}+07$ \\
\hline
\end{tabular}




\begin{tabular}{lll}
\hline Name & Chemical Formula & $e m_{M}\left(x_{M_{c r}}\right)[\mathrm{seJ} / \mathrm{g}$ \\
\hline Vanadium & $\mathrm{V}_{2} \mathrm{O}_{5}$ & $1.64 \mathrm{E}+06$ \\
Zinc & $\mathrm{ZnS}$ & $1.39 \mathrm{E}+06$ \\
Zirconium & $\mathrm{ZrSiO}_{4}$ & $5.18 \mathrm{E}+05$ \\
\hline
\end{tabular}

Table 3: Crustal specific emergy of the main commercially used minerals 
Specific emergy of mineral reserves at their ore grade cutoff

\begin{tabular}{|c|c|c|c|c|}
\hline Name & Chemical Formula & $e m_{R}^{1}\left(x_{M}\right)[\mathrm{seJ} / \mathrm{g}]$ & $e m_{R}^{2}\left(x_{M}\right)[\mathrm{seJ} / \mathrm{g}]$ & $e m_{R}\left(x_{M}\right)[\mathrm{seJ} / \mathrm{g}]$ \\
\hline Aluminium & $\mathrm{Al}_{2} \mathrm{O}_{3}$ & $3.40 \mathrm{E}+09$ & $2.84 \mathrm{E}+08$ & $2.25 \mathrm{E}+07$ \\
\hline Antimony & $\mathrm{Sb}_{2} \mathrm{~S}_{3}$ & $8.10 \mathrm{E}+14$ & $6.75 \mathrm{E}+13$ & $1.86 \mathrm{E}+10$ \\
\hline Arsenic & $F e A s S$ & $2.16 \mathrm{E}+13$ & $1.80 \mathrm{E}+12$ & $8.71 \mathrm{E}+09$ \\
\hline Barium & $\mathrm{BaSO}_{4}$ & $1.71 \mathrm{E}+11$ & $1.42 \mathrm{E}+10$ & - \\
\hline Beryllium & $6 \mathrm{SiO}_{2} \cdot \mathrm{Al}_{2} \mathrm{O}_{3} \cdot 3 \mathrm{BeO}$ & $2.16 \mathrm{E}+13$ & $1.80 \mathrm{E}+12$ & $1.32 \mathrm{E}+12$ \\
\hline Bismuth & $\mathrm{Bi}_{2} \mathrm{~S}_{3}$ & $6.38 \mathrm{E}+14$ & $5.31 \mathrm{E}+13$ & $1.01 \mathrm{E}+11$ \\
\hline Cadmium & $C d S$ & $6.61 \mathrm{E}+13$ & $5.51 \mathrm{E}+12$ & $2.86 \mathrm{E}+12$ \\
\hline Cesium & $C s C l$ & $8.76 \mathrm{E}+13$ & $7.30 \mathrm{E}+12$ & - \\
\hline Chrome & $\mathrm{FeCr}_{2} \mathrm{O}_{4}$ & $1.06 \mathrm{E}+13$ & $8.87 \mathrm{E}+11$ & $1.15 \mathrm{E}+10$ \\
\hline Cobalt & $\mathrm{CoS}_{2}$ & $3.24 \mathrm{E}+11$ & $2.70 \mathrm{E}+10$ & $1.18 \mathrm{E}+10$ \\
\hline Copper & $\mathrm{CuFe} \mathrm{S}_{2}$ & $3.24 \mathrm{E}+11$ & $2.70 \mathrm{E}+10$ & $1.30 \mathrm{E}+09$ \\
\hline Fluoride & $\mathrm{CaF}_{2}$ & $2.43 \mathrm{E}+09$ & $2.03 \mathrm{E}+08$ & $5.60 \mathrm{E}+06$ \\
\hline Gallium & $\mathrm{Ga}(\mathrm{OH})_{3}$ & $9.56 \mathrm{E}+09$ & $7.97 \mathrm{E}+08$ & - \\
\hline Germanium & $\mathrm{GeO}_{2}$ & $6.08 \mathrm{E}+13$ & $5.06 \mathrm{E}+12$ & - \\
\hline Gold & $A u$ & $1.35 \mathrm{E}+13$ & $1.12 \mathrm{E}+12$ & $8.35 \mathrm{E}+18$ \\
\hline Hafnium & $\mathrm{HfO}_{2}$ & $1.12 \mathrm{E}+11$ & $9.32 \mathrm{E}+09$ & - \\
\hline Indium & $\operatorname{In} S$ & $3.24 \mathrm{E}+12$ & $2.70 \mathrm{E}+11$ & - \\
\hline Iron & $\mathrm{Fe}_{2} \mathrm{O}_{3}$ & $2.32 \mathrm{E}+10$ & $1.93 \mathrm{E}+09$ & $4.68 \mathrm{E}+07$ \\
\hline Lead & $P b S$ & $3.24 \mathrm{E}+12$ & $2.70 \mathrm{E}+11$ & $2.66 \mathrm{E}+09$ \\
\hline Lithium & $\mathrm{LiAlSi}_{2} \mathrm{O}_{6}$ & $2.43 \mathrm{E}+12$ & $2.03 \mathrm{E}+11$ & $4.91 \mathrm{E}+11$ \\
\hline Magnesium & $\mathrm{MgCl2}$ & $1.62 \mathrm{E}+08$ & $1.35 \mathrm{E}+07$ & $3.02 \mathrm{E}+05$ \\
\hline Manganese & $\mathrm{MnO}_{2}$ & $6.75 \mathrm{E}+11$ & $5.63 \mathrm{E}+10$ & $1.92 \mathrm{E}+10$ \\
\hline Mercury & $H g S$ & $2.03 \mathrm{E}+13$ & $1.69 \mathrm{E}+12$ & $7.23 \mathrm{E}+12$ \\
\hline Molybdenum & $M o S 2$ & $3.67 \mathrm{E}+12$ & $3.06 \mathrm{E}+11$ & $6.81 \mathrm{E}+11$ \\
\hline
\end{tabular}




\begin{tabular}{|c|c|c|c|c|}
\hline Name & Chemical Formula & $e m_{R}^{1}\left(x_{M}\right)[\mathrm{seJ} / \mathrm{g}]$ & $e m_{R}^{2}\left(x_{M}\right)[\mathrm{seJ} / \mathrm{g}]$ & $e m_{R}\left(x_{M}\right)[\mathrm{seJ} / \mathrm{g}]$ \\
\hline Nickel & $\mathrm{NiS}$ & $7.29 \mathrm{E}+11$ & $6.08 \mathrm{E}+10$ & $3.28 \mathrm{E}+09$ \\
\hline Niobium & $\mathrm{Nb}_{2} \mathrm{O}_{5}$ & $3.05 \mathrm{E}+11$ & $2.54 \mathrm{E}+10$ & - \\
\hline Phosphorous & $\mathrm{P}_{2} \mathrm{O}_{5}$ & $3.42 \mathrm{E}+11$ & $2.85 \mathrm{E}+10$ & $2.27 \mathrm{E}+08$ \\
\hline Platinum & $P t S$ & $3.16 \mathrm{E}+12$ & $2.63 \mathrm{E}+11$ & - \\
\hline Potassium & $\mathrm{KCl}$ & $9.35 \mathrm{E}+13$ & $7.79 \mathrm{E}+12$ & $2.59 \mathrm{E}+07$ \\
\hline Rhenium & $\operatorname{Re} S_{2}$ & $4.86 \mathrm{E}+15$ & $4.05 \mathrm{E}+14$ & $1.16 \mathrm{E}+15$ \\
\hline Selenium & $\mathrm{SeO}_{2}$ & $4.05 \mathrm{E}+10$ & $3.38 \mathrm{E}+09$ & - \\
\hline Silicon & $\mathrm{SiO}_{2}$ & $2.11 \mathrm{E}+09$ & $1.76 \mathrm{E}+08$ & $5.17 \mathrm{E}+05$ \\
\hline Silver & $\mathrm{Ag}_{2} \mathrm{~S}$ & $3.24 \mathrm{E}+12$ & $2.70 \mathrm{E}+11$ & $3.70 \mathrm{E}+13$ \\
\hline Sodium & $\mathrm{NaCl}$ & $1.12 \mathrm{E}+10$ & $9.32 \mathrm{E}+08$ & $3.60 \mathrm{E}+07$ \\
\hline Tantalum & $\mathrm{Ta}_{2} \mathrm{O}_{5}$ & $4.05 \mathrm{E}+11$ & $3.38 \mathrm{E}+10$ & $1.86 \mathrm{E}+14$ \\
\hline Tellurium & $\mathrm{TeO}_{2}$ & $1.62 \mathrm{E}+11$ & $1.35 \mathrm{E}+10$ & - \\
\hline Tin & $\mathrm{SnO}_{2}$ & $1.03 \mathrm{E}+12$ & $8.59 \mathrm{E}+10$ & $1.02 \mathrm{E}+13$ \\
\hline Titanium & $\mathrm{FeTiO}_{3}$ & $5.39 \mathrm{E}+10$ & $4.50 \mathrm{E}+09$ & $7.62 \mathrm{E}+08$ \\
\hline Tungsten & $\mathrm{CaWO}_{4}$ & $4.86 \mathrm{E}+12$ & $4.05 \mathrm{E}+11$ & $4.20 \mathrm{E}+13$ \\
\hline Vanadium & $\mathrm{V}_{2} \mathrm{O}_{5}$ & $6.95 \mathrm{E}+10$ & $5.79 \mathrm{E}+09$ & $3.32 \mathrm{E}+11$ \\
\hline Zinc & $Z n S$ & $7.99 \mathrm{E}+11$ & $6.66 \mathrm{E}+10$ & $1.81 \mathrm{E}+08$ \\
\hline Zirconium & $\mathrm{ZrSiO}_{4}$ & $1.71 \mathrm{E}+11$ & $1.42 \mathrm{E}+10$ & $1.50 \mathrm{E}+12$ \\
\hline
\end{tabular}

Table 4: Specific emergies of mineral reserves at their $O G C$ calculated by different approaches 


\begin{tabular}{|c|c|c|c|c|c|c|}
\hline \multicolumn{7}{|c|}{ Characteristics of Australians mineral reserves } \\
\hline $\begin{array}{l}\text { Mineral } \\
\text { reserve }\end{array}$ & $x_{M_{c r}}$ & $x_{M}^{\circ}$ & $x_{M}$ & $\Delta t[\mathrm{yr}]$ & $\begin{array}{l}e m_{R}\left(x_{M}^{\circ}\right) \\
{[\mathrm{seJ} / \mathrm{g}]}\end{array}$ & $\begin{array}{ll}e m_{R}\left(x_{M}\right) & D \\
{[\mathrm{seJ} / \mathrm{g}]} & {[\%]}\end{array}$ \\
\hline Gold & $\begin{array}{l}1.80 \mathrm{E}- \\
09\end{array}$ & $\begin{array}{l}3.73 \mathrm{E}- \\
05\end{array}$ & $\begin{array}{l}2.02 \mathrm{E}- \\
06\end{array}$ & $1859-2000$ & $6.76 \mathrm{E}+22$ & $4.78 \mathrm{E}+2229.3$ \\
\hline Copper & $\begin{array}{l}2.50 \mathrm{E}- \\
05\end{array}$ & $\begin{array}{l}2.60 \mathrm{E}- \\
01\end{array}$ & $\begin{array}{l}1.33 \mathrm{E}- \\
02\end{array}$ & $1844-2004$ & $1.70 \mathrm{E}+13$ & $1.14 \mathrm{E}+1333.0$ \\
\hline Nickel & $\begin{array}{l}2.00 \mathrm{E}- \\
05\end{array}$ & $\begin{array}{l}4.57 \mathrm{E}- \\
02\end{array}$ & $\begin{array}{l}1.16 \mathrm{E}- \\
02\end{array}$ & $1967-2004$ & $3.07 \mathrm{E}+13$ & $2.52 \mathrm{E}+1317.9$ \\
\hline Silver & $\begin{array}{l}5.00 \mathrm{E}- \\
08\end{array}$ & $\begin{array}{l}3.00 \mathrm{E}- \\
03\end{array}$ & $\begin{array}{l}8.00 \mathrm{E}- \\
04\end{array}$ & $1884-2004$ & $3.94 \mathrm{E}+17$ & $3.47 \mathrm{E}+1712.0$ \\
\hline Lead & $\begin{array}{l}2.00 \mathrm{E}- \\
05\end{array}$ & $\begin{array}{l}7.80 \mathrm{E}- \\
01\end{array}$ & $\begin{array}{l}4.32 \mathrm{E}- \\
02\end{array}$ & $1879-2000$ & $2.87 \mathrm{E}+13$ & $1.98 \mathrm{E}+1330.9$ \\
\hline Zinc & $\begin{array}{l}7.10 \mathrm{E}- \\
05\end{array}$ & $\begin{array}{l}1.70 \mathrm{E}- \\
01\end{array}$ & $\begin{array}{l}8.50 \mathrm{E}- \\
02\end{array}$ & $1905-2004$ & $1.69 \mathrm{E}+12$ & $1.53 \mathrm{E}+129.3$ \\
\hline Iron & $\begin{array}{l}3.50 \mathrm{E}- \\
02\end{array}$ & $\begin{array}{l}6.80 \mathrm{E}- \\
01\end{array}$ & $\begin{array}{l}6.20 \mathrm{E}- \\
01\end{array}$ & $1907-2004$ & $4.70 \mathrm{E}+11$ & $4.50 \mathrm{E}+114.4$ \\
\hline
\end{tabular}

Table 5: Characteristics of Australians mineral reserves 


\begin{tabular}{llllll}
\hline$x_{\text {Copper }}^{\circ}$ & $\begin{array}{l}m_{\text {Copper }}^{\circ} \\
{[\mathrm{kg}]}\end{array}$ & $x_{\text {Copper }_{\text {cr }}}^{\circ}$ & $\begin{array}{l}m_{\text {rem }} \\
{[\mathrm{kg}]}\end{array}$ & $\begin{array}{l}\operatorname{Em}_{\text {Mine }}\left(x_{\text {Copper }}^{\circ}\right) \\
{[\mathrm{seJ}]}\end{array}$ & $\begin{array}{l}E_{\text {Rest }} \\
{[\mathrm{seJ}]}\end{array}$ \\
\hline 0.02 & $1.84 \mathrm{E}+11$ & $2.5 \mathrm{E}-5$ & $1.84 \mathrm{E}+11$ & $7.26 \mathrm{E}+20$ & $1.81 \mathrm{E}+16$ \\
\hline
\end{tabular}

Table 6: Emergy loss and mine restoration of US copper reserves 


\begin{tabular}{lccc}
\hline Inflow & $E x[J / y r]$ & $\tau[s e J / J]$ & $E m[s e J / y r]$ \\
\hline Solar energy absorbed & $3.6 \mathrm{E}+24$ & 1 & $3.6 \mathrm{E}+24$ \\
Crustal heat sources & $1.6 \mathrm{E}+20$ & 20300 & $3.3 \mathrm{E}+24$ \\
Tidal energy absorbed & $1.15 \mathrm{E}+20$ & 72400 & $8.3 \mathrm{E}+24$ \\
\hline Geobiosphere & $3.6 \mathrm{E}+24$ & - & $15.2 \mathrm{E}+24$ \\
\hline
\end{tabular}

Table 7: Global emergy budget of the geobiosphere (Brown and Ulgiati, 2010) 